\title{
EL ROMANCE NAVARRO
}

O. Introducción

Los estudios dedicados a la historia lingüistica de Navarra resultan considerablemente inferiores en número a los suscitados por cualquier otra área iberorrománica, pese a que en el aspecto aludido la situación del reino navarro medieval ofrecía peculiaridades muy características respecto de las de cualquier otro ámbito peninsular.

En efecto, fuentes escritas y diversos testimonios informativos atestiguan la presencia en territorio navarro de dos principales realidades lingüísticas, de muy diversa indole: vascuence y romance. A su vez, este último ofrece dos manifestaciones independientes: una alienigena, occitana; otra autóctona, navarra. Para hacer más completa la enumeración habría que prolongarla con la mención de los núcleos de mozárabes, árabes y judíos. Pero estos grupos carecen de suficiente volumen lingüístico para influir en la caracterización global; por otra parte, estimo que no resultan diferenciales de Navarra. También habría que contar, en rigor, con los emigrantes ultrapirenaicos de lengua de oil; pero, igualmente, a diferencia de los occitanos, no parece que tuvieran ninguna relevancia lingüística. Como simple muestra, si bien muy representativa, de este mosaico idiomático, obsérvese la yuxtaposición de elementos lingüísticos heterogéneos en este fragmento de la enumeración de testigos de un documento (año II76) del monasterio de Irache: "De Stella sunt testes: Petrus Guillem l'arcalt, Bernaldus de Morlans, iaun Petro, don Iofre lo bruter [...] Petro Roiz in Stella. Gil de Lehorin, alcait."

Tal es la peculiar fisonomía lingüística de la Navarra medieval, que lleva a plantear una serie de interrogantes: ¿Cuál era la situación cultural, nivel social, etc., de cada una de las citadas modalidades lingüisticas? ¿Cuál su repartición y extensión geográficas? ¿Qué relaciones guardaban entre sí? La aludida falta de atención a esta parcela de la historia idiomática peninsular impide contestar con precisión a tantas 
preguntas. Pero, en la medida de mis posibilidades, he intentado hacerlo $\mathrm{y}$, en las páginas que siguen, anticipo lo referente al romance navarro; en otra ocasión me ocuparé de las restantes variedades lingüísticas arriba enumeradas.

Antes quiero dejar consignado que las incidentales y rápidas alusiones de orden lingüistico que pueden leerse en obras - generalmente de carácter histórico, documental, etc.- referentes a tema navarro, deforman, en muchos casos, la situación esbozada anteriormente. Un afán, muy explicable, de destacar lo ancestral o, por el contrario, lo exótico $y$, aparentemente, novedoso, mueve a realzar el elemento vascuence o el provenzal ${ }^{1}$ o ambos, con paradójico detrimento del específicamente navarro, en otras muchas ocasiones olvidado o desconocido o confundido con el castellano. En lo que sigue, procuraré precisar la parte de verdad que encierran tales intentos, rectificando las exageraciones en que incurren.

La compleja situación lingüística de la Navarra medieval hace pensar - sin buscar correspondencias estrictas, aunque tampoco faltan- en su diversidad geográfica. Como ésta resulta tan acusada, ha podido afirmarse que "Navarra no es una unidad física, no es un paisaje homogéneo, es una unidad humana» ", para concluir que "la unidad está en la Historia" ${ }^{3}$. En el aspecto lingüistico se llega enseguida a análoga consecuencia trascendente: una voluntad comunitaria políticosocial se impuso sobre las divergencias idiomáticas, que aún no se han reducido a unidad. Sin entrar aquí en detalles del proceso histórico y de sus resultados, es un hecho la convivencia actual de las dos grandes variedades lingüísticas, vascuence y romance, atestiguadas desde los origenes de la Navarra plenamente histórica.

\section{El romance navarro}

Para atestiguar la presencia del vascuence en la Navarra medieval, ha habido que explorar laboriosamente una extensa masa documental, que proporciona unas cuantas palabras aisladas, alguna frase, abundantísima onomástica y diversas noticias, toda vez que falta, en absoluto,

1 Asi suele llawarse, con eviclente error en muchos casos, la lengua de los repobladores francos. Sin entrar alıora en detalles, la denominaré occilano, como ya he hecho anteriormente.

2 J. M. Casas Torris, La originalidad geogrdfica de Navarra. Pamplona, I956, 10.

I Ibid., I8. 
una verdadera documentación propiamente vascuence. A su vez, la presencia de la lengua occitana queda atestiguada, en el mismo ámbito históricogeográfico, por unos centenares de documentos, más que suficientes para una finalidad probatoria, pero, al fin y al cabo, limitados en su número.

Conocido este estado de cosas, se comprenderá que sólo razones muy particulares, antes apuntadas algunas, han podido distraer la atención hacia la lengua romance autóctona de Navarra, que empieza a traslucirse en los textos redactados en latín para llegar pronto a revelarse paladina y abundantemente. Porque, en contraste, con las anteriores variedades lingüísticas citadas, ésta se presenta en una riqueza documental prácticamente ilimitada ${ }^{1}$.

La documentación navarra medieval (derecho privado y derecho público, relaciones, cuentas, textos históricos, etc.) está escrita (con la salvedad, común a las otras áreas lingüísticas peninsulares, del latín, inicialmente, $y$, luego, de la progresiva castellanización) en romance navarro. Puede parecer superfluo e ingenuo sentar tal afirmación, pero estimo indispensable afirmarlo así en un estudio como el presente, para descartar, de una vez, falsas perspectivas (se ha llegado a escribir que toda la documentación privada de Navarra está en provenzal), forjadas más por inadvertencia que por ignorancia de la realidad, que a nadie sorprenderá en cuanto entre en su consideración. Sólo si se desciende a pormenores - si se pormenoriza mucho- habrá que citar la documentación redactada en occitano, puesto que su volumen resulta, comparativamente, menguadísimo. La lengua oficial del Reino de $\mathrm{Na}$ varra - dígase de una vez- era el romance navarro. En ella está escrito -valga recordarlo- el Fuero general de Navarra; en ella se redactan posteriormente los amelloramientos al texto foral.

No parece preciso, pues, insistir en mostrar la existencia y vitalidad del romance navarro, cuya extensión, prácticamente a través de todo el reino medieval - si bien de modo social y geográficamente discontinuo- viene a limitar la difusión que suele atribuirse a las otras entidades idiomáticas del mismo territorio. Es decir, viene a precisar así, indirectamente, el conocimiento de lo que representaban vascuence y occitano en la historia lingüística de Navarra.

1 Sería ridfculo tratar de ofrecer una información cuantitativa, pero, dado el carácter controvertido de la cuestión, no estará de más seũalar que solamente el Catálogo de la Sección de Comptos, del Archivo general de Navarra, lleva publicados 48 volúmenes de índices, que llegan liasta la segunda mitad del siglo Xv. Casi toda esa masa documental, a juzgar por los resúmenes, está redactada en romance navarro. 
Pero no puede dejar de consignarse aquí, por su excepcional interés, un testimonio explícito de la consideración política y social que se concedía al romance navarro. Aunque, naturalmente, ese testimonio se localice en un momento determinado, no parece acertado reducirlo a ese solo momento, sino que habrá que proyectar tal consideración hacia su pasado $y$, con mayor intensidad, hacia el futuro. He aquí el hecho en cuestión, tal como se ha trasmitido en una relación coetánea ${ }^{1}$ de los actos de la coronación de Carlos III, celebrada en Pamplona el dia I3 de febrero de I390.

En elegante latín, como corresponde a la solemnidad y trascendencia del hecho, se van' describiendo diversas ceremonias religiosas y civiles; y sigue el texto, a propósito del rey: "Et in continenti ponens manus suas super crucem et sancta Dey Euangelia, iurautit populo modo et forma conuenienti, in quadam cedulla scripta in ydiomate Nauarre terre, prius palam et publice alta uoce [...] lecta. Cuiusquidem cedulle tenor continet ista uerba: Nos, Carlos, por la gracia de Dios, Rey de Navarra, Conte de Iivreux, juramos a nuestro pueblo de Navarra, es assaber, prelados, ricoshombres, cavailleros, hombres de buenas billas [...] todos lures fueros [...] sen corrompimiento nenguno, meillorando et non apeorando.» Etc.

Este es el testimonio que quería recoger. Al dirigirse a los representantes de todos los estamentos del reino, Carlos III emplea el idioma de la tierra de Navarra. ¿Cuál es ese idioma? Basta seguir leyendo el texto arriba aducido para ver que no es el latín que venía usando el relator, ni vascuence, ni occitano, ni castellano. Cuando el rey, en el momento solemne de iniciar su reinado, se dirige a los suyos, para ligarse a ellos con un juramento, que ha de ser comprendido por todos, utiliza exclusivamente el romance navarro, con la explícita declaración de que ese es el idioma de su tierra.

De idéntica manera, la relación latina se interrumpe en sucesivas ocasiones para recoger los juramentos, igualmente en romance navarro, de los nobles, de los procuradores de las villas, etc.

Me he demorado en referir este suceso porque las circunstancias en que se produce avaloran la información que trasmite sobre la historia lingüística de Navarra. Sin embargo, no es esa la primera vez en que se

1 Se conserva en un espléudido perganino del Archivo general de Navarra, sign. C.59-10, del que trascribo directamente la parte que aqui interesa. Con más extensión lo reproduzco en mi libro, inédito, Textos lingiiisticos navarros. El.documento fue parcialmente publicado por J. YANGUAS y MIRANDA, Diccionario de antigiiedades del Reino de Navarra. Pamplona, $184^{\circ}$ (cito siempre por la $2 .^{2}$ ed., Pamplowa, 1964), I, 203. 
registra una declaración explícita de la existencia del romance navarro. En un documento de $1344^{1}$ se hace constar que "Petro de Laquidayn, scriptori Pampilone, qui de mandato Domini Gubernatoris fecit trasumptum fororum generalis Jacce, Stelle et Superarbi, pro Domina Regina, in ydiomate Navarre, dimittendo totidem spacium in libro pro trasfcrendo dictos foros in ydioma gallicanumin".

Quizá nuevos textos consigan anticipar más la noticia de la toma de conciencia idiomática, es decir, adelantar la datación del hecho ${ }^{3}$. In cualquier caso, los hasta ahora conocidos permiten asegurar que, en la primera mitad del siglo XIV, los navarros ya eran conscientes de poseer su propia -modalidad lingüística romance.

Ahora bien, aunque a diferencia de los casos anteriores no se denominc especificamente tal modalidad, una alusión incidental del Fuero general de Navarra ha de interpretarse con igual sentido que aquéllos. Eu el título I, capítulo I, se prevé el caso de que "fuesse rey ombre de otra tierra o de estranio logar o de cstranio lengoagen. Hay que pensar que el calificativo de cxtraño, 'ajeno', se aplicará por referencia al lenguaje dcl propio fuero. Puede, pues, concluirse que, en la primera mitad del siglo XII, se toma ya al romance navarro como la lengua propia del

1 Citado pot J. M. LACARRa, La formación de las familias de fueros navarros, $A H D E$, I933, IO, 2 I9n. Con anterioridad, J. BORAO, en la introducción a la 2 a $^{\mathrm{a}} \mathrm{d}$. de su Diccionario de voces aragonesas (Zaragoza, I908), dio la noticia, sin citar su fucnte, de que los fueros se copiaron en idiona de Navarra el año 1346 para la Reina.

- J. Ruiz OуaGa, ¿Existe un manuscrito del siglo XIV escrito en euskera?, $B C M N$, 1935, 19, 65-7, con base en el texto arriba citado, supuso que Laquidain era autor de una versión al vascuence del Fuero general de Navarra. Esta suposicion se desvanece con los argumentos que le opuso J. II. IACARRA (iEl Fuero gencral de Navarra, traducido al euskera?, $A H D E$, 1935, I 2, 439-4I): el texto dice irusumplum, esto es, 'copia'. In efecto, Laquidain era simple copista (scriplor): si no copió el iucro en francés (gallicanum), fue porque aún no estaba hecha la traducción y, por tanto, no tenla de dónde copiarla. Por eso, al cncargarle el trabajo, ya se le dice que deje cu blanco una parte para cuando se hiciera dicha traducción.

Tampoco puede suponerse, basándose en la expresion ydiomate Navarre, que copiara un original vasco: cierto que Sanclio el Sabio denomina al vascuence lingua Nauarrorum; pero, además de la distinta extensión de Navarra en el siglo XII que en el Xiv, aquel Rey liahla le los navarros, no de Navarra, es decir, nlude a la lengua de los campesinos ascntados en la región montañosa, la que más propiamente se llamaba Nauarra, de:ınilinación que en el siglo xIV ya encierra un sentido político. Para la Reina (Doña Juana de Iirancia), Navarra es un estarlo con romance distinto del suyo nativo (gallicanum).

- Iin las Cortes celcbradas en Pamplona en septiembre de 1307, fueron romanceadus - scyín una relación coetinca- las cartas latinas que les dirigió el Rey I,uis Inutin, pero no se precisa con ningún calificativo el romance empleado. J. Yancuns y MiRnNDA, Diccionario..., II, 526. 
Reino de Navarra, frente al latín de los documentos y al vascuence de muchos de sus habitantes.

Sépase, sin embargo, que no todos los manuscritos coinciden en la lección consignada; algunos ofrecen linage en lugar de lengoage.

Según la autorizada opinión de Lacarra ${ }^{2}$, ujunto al latín empleado como única lengua en los documentos reales y particulares hasta el siglo XII, se introduce hacia I220 el romance». Pero no se olvide que "el primer texto en que el romance español quiere ser escrito con entera independencia del latín" ${ }^{2}$ son las Glosas emilianenses (mediados del siglo $\mathrm{x}$ ), cuya modalidad lingüística es navarra (cfr. § 4).

\section{Castellano, navarro, navarroaragonés}

Ante el testimonio de declaraciones documentales como las acabadas de referir, resulta aún más sorprendente la ceguera de muchos eruditos, incluso navarros, tan justamente celosos de sus ancestrales valores patrios, para no percibir en la lengua de sus documentos una modalidad diversa del castellano. Antes bien, por el contrario, identifican sin vacilar esa modalidad con el castellano: igual que cuatro siglos antes hacia Nebrija ${ }^{3}$, en el prólogo a su Gramática, pues según él, la lengua castellana que "tuvo su niñez en el tiempo de los jueces y reyes de Castilla [...] se extendió después hasta Aragón y Navarra y de allí a Italian.

Así, Yanguas y Miranda ", reproduciendo una afirmación del P. Moret, asegura, contraponiéndolo al uso del latín, que «el privilegio más antiguo escrito en castellano es del año Ir 7 r, dado por Don Sancho el Sabio a los pobladores de Castellón de Sangüesan; Marichalar y Manrique ${ }^{5}$ afirman que los habitantes del Romanzado y de Navascués "han hablado siempre el castellano desde que de ellos existen noticias históricas»; según Iturralde y Suit 6 , "una parte del pueblo se expresaba

1 J. M. LACARRA, Los documentos navarro-aragoneses, en Los archivos españoles $y$ sus fondos diplomáticos, Madrid, r954, 9.

2 R. AIEnÉndez Pidal, Origcnes del español, Madrid, r950 3, 470.

3 A. DE NebriJA, Gramálica castellana, ed. de P. Gal,INDo y L. ORTIZ MUÑoz, Madrid, 1946, 8. Sin embargo, lineas después, Nebrija considera a los navarros como desconocedores del castellano, al señalar ula necesidad de saber el lenguaje castellano [...] los vizcainos, navarros, franceses, italianos $\mathrm{i}$ todos los otros que tienen algún trato $\mathrm{i}$ conversación en Españav.

- J. Yanguas y Mllranda, Diccionario.... I, 489.

- A. MARIChatar y C. MANRIQUE, Historia de la legislacion, Madrid, I862, IV, 398.

- J. IturRaIdE y SUIT, Las guerras civiles de Pamplona en el siglo XIII. $B C M N, 1917,8,258$. 
en castellano y la casi totalidad en euskara"; para Doussinague 1 "consta que ya desde principios del siglo XII es el castellano el idioma corriente en Navarra»; Elfas de Tejada ${ }^{2}$ cree que "el provenzal, el latín y el castellano son los idiomas usados por la gente culta de la Monarquían.

Por otra parte, debe decirse que la variedad lingǘstica romance de Navarra, rara vez es denominada navarro o romance navarro o dialecto navarro, etc. Por eso estimo que ofrece algún interés consignar aqui algunas excepciones a este uso que, sin haber realizado una sistemática búsqueda intencional, he encontrado. La más notable, sin duda, es la de Sancho y Gil ${ }^{3}$, que reiteradamente emplea las denominaciones de navarro y romañce navarro; por ejemplo, afirma que el Príncipe de Viana "escribió en romance navarro a maravilla" (cfr. §II) o refiere que se "otorga el Fuero de Arguedas en navarro». Más adelante citaré completo un texto de Valdés en el que asevera que "el navarro tiene otros vocablos y otras maneras de dezir" (pero en este texto, como se verá, navarro designa, en mi opinión, al natural de Navarra, no a su lengua).

Ia mancra usual de denominar al habla románica de Navarra es el compuesto navarroaragonés . Así, por citar un caso ilustre, Menéndez Pidal ' habla de idioma navarro-aragonés, dialecto navarro-aragonés, etc. No es otro el proceder terminológico de Amado Alonso, a quien, dada su condición de navarro, he prestado cierta atención a este respecto por si adoptaba una actitud distinta. Pues bien, en su estudio sobre el catalán ${ }^{6}$, alude en varios pasajes al dialecto navarro-aragonés; sólo en uno habla del navarro, equiparándolo a otras variedades peninsulares, a propósito de la "conservación de $-m b$ - en leonés, portugués y navarro» ${ }^{7}$.

2 J. M. Doussinague, La guerra de la Navarreria. PV, 1945, 6, 210.

2 F. ELfAS DE TEJADA, La literatura politica en la Navarra medieval. $P V$, 1956, I7, 201.

- I’. Sancho y GII, Prólogo (1884) a J. Borao, Diccionario..., CXVI y CXXX.

- Téngase en cuenta, de una vez por todas, que los casos en que aparece el compuesto con guión entre sus dos elementos, no indican que se trate de una yuxtaposición conceptual de dos realidades diversas, como pudiera creerse de acucrdo con las últimas disposiciones ortográficas de la Real Academia Espaiola, posteriores a los testimouios citados.

8 R. MENÉNDEZ PIDAL, Origenes..., 465 y 466. No obstante, en otras obras (cfr. § II) dirá que el Príncipe de Viana escribe en navarro o aludirá a los dialectalismos navarros del Roncesvalles.

- A. Alonso, La subagrupación románica del catalán. RFE, 1926, 13, I-38, 225-26r. Recogido en Estudios lingüisticos. Temas españoles, Madrid, r95I.

7 Ibid., 35. En este caso, la denominación de navarro, a secas, viene proba. blemente forzada porque en territorio aragonés, como es sabido, no se verifica la citada conservación. 
En su libro sobre los nombres del habla de Castilla ${ }^{1}$, no hay la menor referencia a la modalidad lingüística navarra, mientras que, para aclarar su concepto de tierra, lo ejemplifica pormenorizadamente con denominaciones geográficas de Navarra. 'lampoco utiliza una denominación especifica al estudiar - fundamentalmente en territorio navarro- la pronunciación del grupo $\mathrm{tr}^{2}$. En otro navarro, Ynduráin ${ }^{3}$, se encuentra igualmente el compuesto navarro-aragonés varias veces, desde el título mismo del estudio citado; en un trabajo posterior 4 emplea repetidamente la denominación navarro antiguo.

También en $\mathrm{X}$. Malkiel (Paradigmatic resistance to sound change. Lang, I960, 36, 288) encuentro, junto a Navarro-aragonese, la distinción de Old Navarrese e, incluso, some Old Navarrese subdialects (including the one which has served as a vehicle for the Fueros de la Novenera).

En el rico Vocabulario navarro, de Iribarren ${ }^{5}$, el adjetivo del título posee un carácter exclusivamente geográfico; su autor no se propone establecer ninguna diferenciación lingüística. Essto se deduce fácilmente del hecho de que muchos de los materiales recogidos sean comunes con el castellano coloquial de diversas regiones; otros, por el contrario, son vasquisinos.

Nuevos testimonios de todas las denominaciones aqui ejemplificadas se irán viendo, como es natural, a lo largo del presente estudio.

\section{El conocimiento del romance navarro}

El breve examen terminológico del capitulillo anterior ofrece algún interés mayor que la mera constatación de unas denominaciones. Pues lleva a la conclusión de que en los estudios lingüísticos la identificación de la lengua románica de Navarra con la de Aragón se da por supuesta o ha alcanzado el rango de doctrina de general aceptación: no de otro modo puede entenderse esa unanimidad en la denominación navarro-aragonés.

Resulta difícil, sin embargo, justificar cómo se ha procedido para afirmar esa identidad, pues no se ha llegado a ella a través de un pro-

1 A. Aronso, Castellano, español, idioma nacional. Buenos Aires, $195^{3}$, $32 n 3$.

2 A. Alonso, El grupo tr en España y América. HMP, I925, II, I67-9I. Recogido en Iistudios lingïísticos. Temas hispanoamericanos. Madrid, I953.

- F. YNDURAIN, Contribución al cstudio del dialecto navarro-aragonés antiguo, Zaragoza, I945.

- F. YNdur.ún, Documentos de la iglesia de Santa Maria de Sangïesa. Pir, $1948,4,323-54$.

- J. M. IRIBARREN, Vocabulario navarro, Pamplona, 1952. 
ceso regular de estudios previos. Antes bien, parece que un sentimiento - conciencia tradicional y generalizada de la igualdad lingüística de ambas regiones es el que se ha impuesto en el ámbito científico, aceptado por éste sin crítica detenida. La razón para estimarlo así se presenta, a mi juicio, evidente: si para el habla de Aragón se ha superado descle liace bastantes años la "conspiración del silencio" que, según se pudo afirmar ${ }^{1}$, pesaba sobre ella, al habla de Navarra, por el contrario, se ha prestado aún escasísima atención. Las pocas monografías que se le han dedicado son, todas, recientes, muy posteriores a la afirmación de la identidad susodicha. Ciertamente que, en el estado actual de conocimientos sobre la cuestión, todo lleva a suponer, al menos en sus grandes líneas, la realidad de tal identificación; pero faltan aún muchas prucbas positivas, explícitas, en que asentar la igualdad aceptada.

No resulta temerario asegurar que nada semejante, ni remotamente, a lo que ha hecho Monge ${ }^{2}$ con el dialecto aragonés puede hacerse respecto de Navarra, porque no hay apenas materia para ello. La lectura del documentado artículo de Monge ofrece también interés para el fin presente por otra razón: en las múltiples referencias por él acumuladas, no se cita jamás específicamente a Navarra ni se alude a su relación lingüistica con Aragón. De modo análogo, la falta de estudios previos y de clarificación de la cuestión hace que en una obra de conjunto sobre cl dialecto aragonés, su autor ${ }^{3}$ proceda así: "Consideraré lo navarro siempre que me pueda facilitar algún motivo de claridad o de contraste, pero no sistemáticamente (por eso faltan mis referencias a sus colecciones diplomáticas, aunque he usado algunas)". Debe, pues, concluirse, que la escasez de monografías sobre el habla rcmánica de Navarra ha determinado que la caracterización del dialecto llamado navarroaragonés se haya realizado sin contar apenas con datos provenientes del área navarra. Supuesta la identidad de esta área con la aragonesa, en la práctica la doctrina más común atribuye al habla antigua de Navarra los rasgos de la de Aragón. Independientemente de la verdad que en ello pueda haber, debe subrayarse que falta, por tanto, en muchos casos, la verificación objetiva de tales características. Aunque pueda hablarse de un dialecto navarroaragonés, se carece aún del conocimiento directo del factor navarro integrante de ese conjunto.

Antes de terminar esta perspectiva, tan desoladora, del estado de conocimiento del romance navarro, debe hacerse una mención expresa,

$1 \Lambda$. Alonso, La subagrupación...., $52 n$.

2 F. MONGE CASAO, Notas para la historiografía del habla de Aragón. BRAE, I95I, 3I, 93-I 20.

2 M. ALVAR, El dialecto aragonés, Madrid, 1953, I $33 n$. 
por su temprana fecha, aun dentro del panorama dialectológico español, del opúsculo que en I854 publicó en Pamplona J. Yanguas y Miranda con el título de Diccionario de las palabras anticuadas que contienen los documentos existentes en los archivos generales $y$ municipales de Navarra $y$ de su correspondencia con el lenguaje actual. Con anterioridad a ese año ya habia publicado Yanguas varias obras de carácter histórico y jurídico $(\S 4)$ que encierran interés lexicográfico. Yanguas, como ya se ha visto antes $(\S 2)$, no era consciente de la existencia de un romance navarro, que identifica con el castellano; asi, en el prólogo del citado Diccionario, justifica su labor por la utilidad que supone para la uhistoria de la marcha de nuestro idioma castellano". Sin embargo, Yanguas, pese a su grave error de principio, fue el pionero de los estudios sobre el habla antigua de Navarra, sin que desgraciadamente tuviera sucesor inmediato.

\section{Fuentes $y$ estudios}

La documentación medieval navarra, probablemente por no haber alcanzado la publicación más que de modo muy cscaso, en obras poco difundidas o asequibles (muchas veces se encuentra en apéndices documentales, reducidos, de monografías históricas difíciles de conocer salvo por el especialista), apenas ha llegado a despertar el interés, ni siquiera a llamar la atención de los filólogos. En mi opinión, ahí radica la causa principal de los escasísimos estudios de esa orientación realizados sobre textos navarros, muy inferiores en número, como indiqué al principio de esta exposición, a los suscitados por cualquier otra variedad lingüística peninsular. Sin embargo, el panorama ha mejorado sensiblemente en los últimos años ${ }^{1}$.

1 Otra causa determinante de esta deficitaria situación procede de la inexistencia ell Navarra, hasta época reciente, de un centro de estudios superiores, en el que se pudiesen realizar tales investigaciones. Estimo que el porvenir se presenta, a este respecto, optimista: realizadas y en curso de realización existen bastantes tesis de licenciatura y doctorado, de carácter documental, en la Universidad de Navarra. Ia cual, en cooperación con otras entidades (Centro de Estudios Medievales, de Zaragoza; Instituto de Estudios Pirenaicos, etc.) ha iniciado una colección de Fuentes para la historia del Pirineo (cfr. J. Coromanas, On an important new source for Upper Aragonese and North Western Catalan. Homage to John MI. Hill. Indiana University, I968, 3x9-36) de la que han aparecido ya varios volúmenes, entre los que son de capital importancia los dedicados a la documentación de Irache, cuyo estudio filológico ya se ha iniciado, por C. Saralegui, así como el de otros textos de interés lingüistico. 
Faltan, igualmente, los estudios descriptivos sobre el habla viva de Navarra (sin ducla, por la causa apuntada en la última nota), aunque también en trance de remediarse esta situación deficitaria ${ }^{1}$.

Tal penuria de estudios y de información me ha decidido a ofrecer una visión panorámica de las principales fuentes impresas, en función de su interés, volumen, etc. Del mismo modo, intentando, en este caso, llegar a una nómina completa, proporcionaré noticia de los estudios realizados, tanto sobre el habla antigua como sobre la moderna.

\section{Glosas}

Annque resulta difícil fijar con precisión la modalidad lingüistica propia de las Glosas emilianenses (cd. de R. Meuéndez Pidal, Origenes del español, Madrid. 1950, pp. 3-9), estimo que pueden ser consideradas como la primera manifestación del habla navarra. Con base en un rasgo de las glosas en vascuence, Mrenéndez Pidal scũala que uel glosador de San Millán parece, pues, un navarron; aunque poco después afirma que ren estas Glosas emilianenses vemos el habla riojana del siglo $x$ muy impregnada de los caracteres navarro-aragoneses" ${ }^{2}$, resulta evidente que el habia riojana no podia estar apenas diferenciada de la navarra, máxime teniendo cn cuenta que Rioja pertencela aún a los reyes navarros.

Respecto de las Glosas silenses (ed. de $R$. Menéndez Pidal, ibid., II-24), usi por la escritura de su amanuense son tan castellanas como lo que se escribla por los monjes de las orillas del Arlanza, por su lenguaje son tan riojanas, casi, como lo que se escribia en las celdas de San Millán. Son riojanas o navarras, lo nuismo que las Glosas Emilianensesn, afirma Menéndez Pidal. Tras señalar varios rasgos fonéticos (conceillo, mutilo, aplecan, clamando, yet) comunes con estas últimas, precisa que "todavia las sileuses tienen otros suyos que también son navarros, como la diptongación ante yod ell siej'at 'sea'; el subjuntivo prencat 'prenda' y aún podrian contarse como navarrismos el posesivo lures faces, y la confusión del tema de perfecto sapieret 'supjere', abierat 'bubiera'». Por el contrario, otros caracteres acercan las Glosas silenses "más a Castilla que a Navarra, por ejemplo. el carecer de vacilación en el diptongo ue, ua». Concluye Menéndez Pidal: aes de suponer que todos estos rasgos navarro-riojanos que hemos apuntado no eran comunes a la alfoz de Lara, sino que eran el lenguaje individual del monje glosador. que queria seguir el patrón de los escritos usuales en el monasterio navarro de San Milllán" ${ }^{3}$.

1 Según mis noticias, están terminadas las encuestas de la zona navarra para el Atlas lingiḯslico y etnográfico de Aragón, Navarra y la Rioja, que realizan M. Alvar, A. Llorente y T. Buesa. Hay varios estudios, en preparación, sobre el habla de algunas localidades. Il proyectado Atlas lingüistico del País Vasco, en cl que intervienen, entre otros, L. Michelena y A. MI. Echaide, beneficiará también el conocimiento del erdera navarro.

2 R. MENÉNDEZ PIDAL, Origenes..., 470.

- Ibid., 485 . 


\section{Textos legales}

Del Fuero general de Navarra existen numerosos manuscritos, cuya genealogla no está bien establecida. Hay ediciones de Pamplona, I686 (con una breve tabla de los vocablos mós oscuros), I815 (con un Diccionario para facilitar la inteligencia de estos fueros, por F. Baráibar de Haro) y I869; esta última, debida a P. Ilarregui y S. Lapuerta, ha sido reeditada ell Pamplona, 1964, tactualizaudon el glosario de la edicibul de 1869, que, a su vez, corregia y aumentaba el de I815. No obstante, en su estado actual sigue siendo muy inperfecto dicho glosario, lo mismo que la fijación del texto. Para el aspecto lingǘstico del Fuero general, F. Ynduráin, Contribución al estudio del dialecto navarro-aragonés antiguo (Zaragoza, x945) '; para aspectos históricos y juridicos, J. M. Lacarra, Sobre el Fuero general y stis fuentes (BCMN, 1928, 2, 302-6) y R. Gibert, Fuero general de Navarra (en Nueva enciclopedia jurtdica, Barceloua, 1960, X, 32I-6).

Los Fueros de la Novenera han sido publicados por G. Tilander (Upsala, I95I), con estudio gramatical y vocabulario ?. Para su caracterización judfdica, $R$. Gibert, El derecho medieval de la Novenera (AHDE, I95I-2, 21-2, I I69-122I).

Del Fuero de Viguera $y$ Val de Funes hay edición de J. Mr. Ramos Loscertales (Salamanca, 1956).

Algunos fragmentos del Fuevo de Tudela figuran en la edición del Fuero de Jaca, realizada por $M$. Molho (Zaragoza, 1964 ). En el mismo volumen se encuentra la versión navarra de este último fuero, realizada por Garcla Martínez, notario de Villafranca.

Varias Ordenanzas municipales de Estella fueron publicadas por J. M. Iracarra ( $A H D E$, 1928, 5, 434-45, y $P V$, 1949, 10, 405-24); las reproducidas ell esta última revista llevan un estudio lingüístico de $F$. Yuduráin.

A S. Garcia Larragueta se debe la edición de varios Fueros y cartas pueblas navarro-aragonesas otorgadas por templarios y hospitalarios (AHDE, 1954, 24, 587-603).

Para un examen de conjunto de los fueros navarros puede verse J. M. Lacarra, Notas para la formación de las familias de fueros navarros ( $A H D E, 1933,10,203-52$ ).

Omito la mención de los textos legales no redactados en romance navarro.

Debo hacer ahora una excepción para dar cuenta del volumen que inicia una ambiciosa serie de Fueros de Navarra. Se trata de la cuidadosa edición de Fueros derivados de Jaca. I. Estella-San Sebastián, por J. M. Lacarra y A. J. Martin Duque. Pamplona, I969. Comprende las versiones latinas y romances (occitano) del Fuero de Estella y la latina del Fuero de San Sebastián, más 20 piezas documentales cuyas fechas van de rogo a 1365.

1 Reseñas: S. GIII GAYA, BBMP, 1945, 2I, 193-4; J. ALDA, RFE, I945, 29, 374-5; K. S. ROBERTS, HR, I946, I4, 368-7r; A. BADIA, Pir, I948, 4, 621-2.

2 Reseñas: J. VIDar, PÍlkez, RDTP, I95I, 7, 539-40; F. LÓPEZ EsTrada, AUH, I95I, I2, 69-70; G. MOLDINIAUER, Fil, I95I, 3, 223-7; G. M. BERTINI, QIA, 1952, 2, 210-I; A. GRIERA, BDE, I952, 31, 6I-5; A. HIENRY, RBPH, 1952, 30, 562; 15. INDURAIN, RFE, 1952, 36, 145-6; F. S. IJEAR, Sp, I952, 27, 429-31; L. Mourus, Script, 1952, 6, 168; B. PoTtreR, AIL, 1952, 5, 379-82; G. ROFIFS, ASNS, 1952, I89, 93-4; K. SNEYDERS, $N$, 1952, 36, 186-7; J. BOURCIEZ, $R L R$, 1952, 7I, 226; E. K. NEUvONEN, StN, 1952, 25, 80-2; M. ALVAR, I953, 6, 320-4; W. D. ELCOCK, $M L R, 1953$ 48, 88; W. GIESE, ZRPh, 1953, 69, I55-7; C. CREWS, $R P h, 1955,9,232-7$. 


\section{Colecciones documentales}

Deben destacarse, por su riqueza o interés, las siguientes colecciones, que cuumero por orden de antigüedad:

J. A. Brutails, Documents des archives de la Chambre de Comptes de Navarre. Paris, 1890 .

M. Arigita y Lasa, Colección de documentos inéditos para la historia de Navarra, I. Pamplona, 1900.

M. Arigita y Lasa, Cartulario de Don Felipe IIJ, Rey de Francia. Madrid, I9r 3.

G. Berrogain, Documentos para el estudio de las instituciones politicas de $\mathrm{Na}$ varra durante las dinastias de Champagne y de Francia. AHDE, 1929, 6, 462-522.

I. Iscalada, Documentos históricos del Castillo de Javier. Pamplona, I93 I.

C. Marichalar, Colección diplomatica del Rey Don Sancho VIIJ el Fuerte ile Navarra. Pamplona, 1934.

J. M. I,acarra, Documentos para la historia de las instiluciones navarras. AHDE, I934, II, 487-503.

I. Fuentes Pascual, Documentos del archivo del convento de Santa Clara de Tudela. Zaragoza, I940.

J. M. Iacarra, Documentos para el estudio de la reconquista $y$ iepoblación del Valle del Ebro. EEMCA, 1946, 2, 469-546; 1947-8, 3, 499-727; 1952, 5, 51 I-618.

I. Yndurain, Documentos de la iglesia de Santa Marta de Sangiiesa. Pir, I94., 4. 323-50 (con estudio lingüístico del editor).

Rescĩa por B. Potticr, Fil, 1950, 2, 93-4, con algunos datos.

A. Ubicto, Colccción diplomálica de Pedro I de Aragón y Nuvarra. Zaragozn, 1952 .

IF. Idoate, Un formulario de la cancilleria navarra del siglo $Y V$. AHDE. I956, 26, $517-646$.

S. Garcia Larragueta, El gran priorado de Navarra de la Orden de San Juan de Jerusalén, II. Colección diplomálica. Pamplosna, $1957^{1}$.

J. M. Lacarra, Colección diplomática de Irache, I. Zaragoza, I965.

J. M. Jimeno Jurio, Documentos medievales artajoneses. Pamplona, I968.

C. Asensio, Colección diplomática de Gaviia Ramirez (inédita).

A. Bermejo, Documentos de García de Nájera (1035-1044) (inédita).

J. Soria, Documentos de Garcia de Nájera (1045-1054) (inédita).

A. Ardanaz, Documentos de Leire (842-1076) (inédita).

E. Ederra, Documentos de Leire (1079-I102) (inédita).

A. Guibert, Documentos de Leire (II02-II22) (inédita).

11. J. Lizarraga, Documentos de Leire (II22-I202) (inédita).

N. I. Fernández Gago, Documentos de Leire (I 201-1270) (inédita).

In la mayoria de estas series se recogen documentos romances y latinos, reales y privalos. No consigno las colecciones que comprenden exclusivamente documentos latinos, reales o eclesiásticos, o en romance no navarro, por caer fuera del interés buscado. Prescindo también de las antologias de textos medievales - dialectales, como las muy conocidas de Gifford y Hodcroft, Menéndez Pidal, Alvar, etc.

1 Reseñas: J. G. G., Hispania Sacra, 1956, 9, 46I-4; F. I., PV, 1957, I8. 474-5; A. J. MARTfN DuQUE, EEMCA, 1962, 7, 772, 809-Io. 
Para una caracterización diplomática de la documentación navarra, resulta muy útil la lectura de J. M. Lacarra, Los documentos navarro-aragoneses (en Los archivos españoles y sus fondos diplomálicos. Madrid, I954, 7-10).

Otras fuentes doctmentales

En los siguientes estudios, que cito por orden de publicación, aparece, generalmente en apéndice, documentación navarra de cierto volumen o interés:

G. B. Lagrèze, La Navarre franqaise. Parts, I881.

A. Rubio y Iluch, Los navarros en Grecia. Barcelona, 1886.

P. Boissonnade, Histoire de la rénnion de la Navarre d̀ la Castille. Parts, 1893.

M. Arigita y Lasa, Historia de la imagen y santuario de San Miguel de Excelsis. Pamplona, 1904.

E. Ibarra, Cristianos y moros. Documentos aragoneses y navarros, en Homenaje a Don Francisco Codera. Zaragoza, I904, 79-92.

J. M. Lacarra, Notas para la formacion de las familias de fueros navarros. $A H D E$, 1933. IO, 203-52.

J. R. Castro, Lealtad de Tudela a los Reyes de Navarra, en Revista Zurita, I933, I, I7-37.

J. Ibarra, Historia de Roncesvalles. Pamplona, 1935.

P. Galindo Romero, Peregrinación de Doña Blanca de Navarra en 1433 a Santa Marta del Pilar de Zaragoza, en Revista Zurita, I935, 3, II-4I.

J. Zunzunegui, El reino de Navarra y su Obispado de Pamplona durante la primera época del cisma de Occidente. San Sebastián, I942.

E. Śez, Un robo al monasterio de Leyre a principios del siglo XIV.PV, I945, 6. $559-64$.

M. Núñez de Cepeda, Los antiguos gremios y cofradías de Pamplona. Pamplona, 1948.

A. M. Berazaluce, Las joyas de la infanta Isabel. PV, 1948, 9, 221-2.

L. Vázquez de Parga, J. M. Lacarra y J. Uria, Las peregrinaciones a Santiago de Compostela. Madrid, 1949, III, 14 y passim.

J. R. Castro, El canciller Villaespesa. PV, 1949, I0, 129-226.

J. Pérez dé Urbel, Sancho el Mayor de Navarra. Madrid, r950.

J. Albizu, Catálogo general del archivo de la parroquia de San Saturnino de Pamplona. Pamplona, 1950 (la I.a ed. no contiene documentación).

J. J. Uranga, La población de la Navarrerta de Pamplona en 1350. PV, 1952, I3, 67-104.

J. Goñi, Nuevos documentos sobre la catedral de Pamplona. PV, 1953, 14, 3II-27: 1955. I6, I33-200.

F. Idoate, Rincones de la historia navarra. Pamplona, I, I954; II, I956; III, I966.

J. Goñi, El Cardenal Besarión y la guerra civil de Navarra. Anthologia Annua, I956, 4, 239-82.

F. Idoate, El Señorio de Sarria. Pamplona, 1959.

M. A. Irurita, El Municipio de Pamplona en la edad media. Pamplona, 1959.

S. Solá, Peleas conventuales por un salmón. Miscelánea Antonio Pérez Goyena. Madrid, 1960, 453-64 (con breve caracterización lingüistica del documento publicado).

J. J. Uranga, Documentos sobre la población de Navarra en la edad media. PV. I961, 22, 137-I76; 1962, 23, 243-89. 
A. J. Martín Duque, La comunidad del Valle de Salazar. Pamplona, 1963.

J. R. Castro, Carlos III el Noble, Rey de Navarra. Pamplona, I967.

M. C. Saralegui, El testamento de Carlos III. Edición critica, estudio lingüústico $y$ vocabulario (en prensa).

In el Boletin de la Comisión de Monumentos de Navarra (1895-1936) se encucntran publicados uumerosos documentos navarros; su escaso interés lingüistico justifica que no se incluyan en la anterior relación.

\section{Texlos históricos}

Además del Liber Regum, de la Crónica general de España, de Fray Garcia de İugui, de la Crónica, de Garcia Isópez de Roncesvalles, y de la Crónica de los Reyes de Navarra, del Principe de Viana, obras especialmente examinadas en $\S$ II, hay que mencionar las noticias gencalógicas que recogen, en su final, algunos manuscritos del Fuero general de Navarra. Con la denominación de Corónicas navarras (Valencia, 1964 ) han sido editadas por A. Ubicto, para quien estos breves textos tuvieron vida independiente, auterior a su inclusión en la compilación legal.

También hay que citar en este apartado la relación Desde Estella a Sevilla. Cuentas de un viaje (1352). Ed. de M. D. Sánchez Villar (Valencia, 1962).

Bajo el título de Libro de las generaciones, J. Ferrandis ha publicado (Valencia, I968) un manuscrito asi denominado, de letra del siglo xvi, copiado por Martín de Larraya. Del examen de los sucesos consignados en el texto deduce la editora que fue escrito entre 1258 y 1270 .

La obra ofrece escaso interés histórico y ningúu valor literario; pero sí lingüistico. Pucs aunque se trata de un texto relativamente temprano, el carácter tardio de la copia conservada hace sorprendente que en época tan avanzada persistan con intensidad múltiples rasgos del dialecto navarro, por cuanto descie fines del siglo $\mathrm{xv}$ - $\mathrm{y}$ aun antes - la lengua de la documentación navarra aparece profundamente castellanizada. Esto es lo que ocurre de modo general a otros textos históricos navarros contemporáneos de la versión presente (pienso en la Crónica de los Reyes de Navarra, de Diego Ramirez Dávalos; en la anónima Suma de las crónicas de Navarra; etc.), en la que la castellanización resulta muy escasa (son usuales las formas como fillo, muller, nompne, etc.; sólo excepcionalmente se encuentran fijo, muger, nombre, etc.).

\section{Textos literarios}

Mie ocupo especialmeute de ellos en $\S$ II.

\section{Caldlogos de archivos}

E. Munárriz Urtasun, Los pergaminos de Leyre. $B C M N, 1923,14,237-4 \mathrm{I}$; 1924, 15, 13-7.

J. Albizu, Catálogo general del archivo de la parroquia de San Saturnino de Pamplona. Pamplona, 1925; 1950².

F. Fuentes Pascual, Catálogo de pergaminos del archivo del Palacio Decanal de la ciudad de Tudela. Zaragoza, 1937. 
F. Fuentes Pascual, Catdlogo de los archivos eclesidsticos de Tudela. Tudela, I944.

F. Fuentes Pascual, Caldlogo del archivo municipal de Tudela, I. Tudela, 1947.

J. R. Castro, Catdlogo de la Sección de Comptos. Archivo general de Navarra. Pamplona, I952-, en curso de publicacion. Ultimo volumen, XIVIII, I968. Desde el vol. XXXVII, bajo la dirección de F. Idoate.

J. M. Lacarra, Guta del archivo general de Navarra. Pamplona. Madrid, I953.

F. Idoate, Catalogo docimental de la ciudad de Corella. Pamplona, r964.

J. Goñi, Catdlogo del archivo catedral de Pamplona, I (829-1500). Pamplona, I965.

Estudios sobre el habla antigua

Además de los estudios que se indican en los apartados anteriores, en relación con algunos de los textos consignados, y de los correspondientes a textos literarios ( $(I I)$, han de citarse aquí los siguientes, por orden de antigüedad:

J. Yanguas y Miranda, Diccionario de los fueros del Reino de Navarra $y$ do las leyes promulgadas hasta 1818. San Sebastián, 1828-9, 2 vols.; Pamplona, 1964².

J. Yanguas y Miranda, Diccionario de antigüedades del Reino de Navarra. Pamplona, 1840; 19642, 3 vols.

J. Yauguas y MIiranda, Diccionario de las palabras anticuadas que contienen los documentos existentes en los archivos generales y municipales de Navarra $y$ de su correspondencia con el lengunje actual. Pamplona, 1854.

J. Yanguas y Miranda, Diccionario histórico politico de Tudela. Zaragoza, 1823.

C. Corona Baratecl, Toponimia navarra en la edad media. Huesca, 1947 (prólogo de I: Ynduráin).

I. Baleztcua, Toponimia del término de Pamplona. Actas de la primera reunión de toponimia pirenaica. Zaragoza, I949, 59-63.

B. Pottier, Notas lingiilsticas sobre antiguos texlos aragoneses. $A F A, 1950$, 3, 227-50 (analiza sucintamente algunos documentos navarros comprendidos entre I129-97, en las pp. 229 y 232-6.

M. Alvar, Grafias que representan fonemas palatales en los documentos navarroaragoneses de la edad media. Arg, 1952, 3, 237-48.

M. Alvar, Grafias navarro-aragonesas. Pir, 1953, 9, 55-85.

D. J. Gifford, The place-names of Navarra: $A$ brief survey. Actes, $V^{*}$. Congrès int. de Toponymie. Salamanca, I958, II, I7-28.

I. R. Nacpherson, Associate interference in object-pronoun combinations in Navarre and Aragon. BHS, I96r, 38, 28-3I.

He prescindido de los estudios, relativamente numerosos, de onomástica, lexicografia, geografía liugüística, etc., que se interesan especificamente por el vascuence en Navarra. Véase su nómina en mi estudio Vascuence y romance en la historia lingüistica de Navarra.

Estudios sobre el habla moderna

A. Alonso, El grupo tr en España y América. HMP, I925, II, 167-9r; recogido en Estudios lingïlsticos. Temas hispanoamericanos. Madrid, 1953. 
W. Bergmann, Shudien zur volkstïmlichen Kullur im Grenzgebiet von Hocharagon und Navarra. Hawburgo, $1934^{1}$.

J. Corominas, Los nombres de la lagartija y del lagarto en los Pirineos. RFH, 1943. 5, I-20.

M. Alvar, El habla de Oroz-Betelu. RDTP, 1947, 3, 447-90.

- M. Alvar, Palabras y cosas en la Aezcoa. Pir, 1947, 3. 5-38; 263-315 2.

M. Alvar, Los nombres del arado en el Pirineo. Fil, I950, 2, I-28.

J. M. Iribarren, Vocabulario navarro. Pamploua, I952 (prólogo de F. Yaduráin).-Adiciones al vocabulario navarro. Pamplona, $195^{3}$.

M. Alvar, El fuego y el lexico con el relacionado en la Navarra nordoriental. MLiscelánea filológica dedicada a Mons. A. Griera. Barcelona, 1955, I, I5-36.

A. M. Echaide, Léxico de la viticuliura en Olite (Navarra). PV, I969, 30, $147-78$.

Tampoco recojo en cste apartado los estudios dedicados al vascuence en $\mathrm{Na}$ varra. İ̀n § II doy noticia de algunas obras literarias que en notas a pie de página o en un glosario final recogen voces caracteristicas.

\section{Origenes del romance navarro}

Los orígenes del romance navarro, como los de las restantes modalidades lingüísticas peuinsulares, van intimamente vinculados a cuestiones de orden político, social y cultural. Si se tiene en cuenta la inseguridad con que los historiadores presentan la aparición de los núcleos iniciadores de la Reconquista en la región pirenaica 4, las profundas disdiscrepancias entre tales historiadores; el frecuente recurso a hipótesis para llewar las lagunas de información documental, etc., se comprenderá bien la dificultad que se presenta para explicar los orígenes romáuicos de la zona navarra.

Pero si esta problemática situación resulta común -aunque quizá aquí en mayor escala - con otras áreas peninsulares, en el presente caso se alza un nuevo problema, de orden intrínsecamente lingǘstico: Puesto que está perfectamente atestiguada la existencia del vascuence desde tiempos muy anteriores $y$, sobre todo, hasta tiempos muy poste-

1 Reseñas: W. BIERHENKE, $B B G E$, r934, 7, 80-I; K. IV. ASNS, 1934, 166, 153-4; F. MOLI, $B D L I C, 1935,17,142-3$; E. BOURCIEZ, $B H$, 1935, 37, 254-6; A. Kunn, $Z R P h, 1936,56,696-701$.

- Reseña de los dos últimos estudios, y otros, de este autor: IF. KRüGER, Fil, I95x, 3, I18-30.

- Reseñas: A. YRIGaray, BSVAP, I952, 8, 529-32; J. Roca, Pir, I953, 9. 145: G. RonLFS, $A S N S$, I953, I90, 367-8; F. KRUGER, $A I L$, I957, 6, 457-6I; A. CASTILLO DE LUCAS, RDTP, I958, I4, 524; L. MCUULLENA, BSVAP, I959, 13. 81-3; W. GLESE, BICC, I959, I4, 286-8.

- Cfr. cspecialmente C. SÁncinez Albornoz, Problemas de la historia de Navarra del siglo $I X . P V, 1959,20,5-62$, monografia de la que, en efecto, se saca una firme idea de los problemas, pero no - dicho sea sin ninguna ironiade las soluciones. 
riores, en la misma área, ¿cómo explicar el surgimiento de una lengua romance en un medio lingüístico radicalmente diverso? ${ }^{1}$ Constituye, pues, este fenómeno un problema especifico de Navarra, insoslayable, previo a cualquier otra consideración sobre la nueva entidad idiomática; pero que, en mi opinión, ni siquiera ha sido abiertamente planteado. Urge, por tanto, tratar de conseguir una solución aceptable.

A la vista de los hechos históricogeográficos, en absoluto puede explicarse la situación resultante como debida a la invasión progresiva, desde la periferia del dominio vascohablante, de una lengua alienigena ya constituída. La regresión del vascuence en Navarra - bajo el aspecto. geográfico, no bajo el social- parece prácticamente nula durante la Edad Media y muy lenta en los siglos inmediatamente siguientes. Sólo. en tiempos modernos se precipita, cuando ya está arraigado profundamente el romance, con múltiples manifestaciones, en el interior del pais.

Iimitándose a los datos históricos que hoy por hoy aparecen mejor fundados y gozan, por tanto, de máxima aceptación ${ }^{2}$, se puede dar por cierto que a principios del siglo $x$ una nueva dinastía, la estirpe Jimena, comienza a regir el Reino de Pamplona. Esa estirpe procedía de la zona de Sangüesa y Leire: precisamente el área más cristianizada, más romanizada, de la periferia de la Navarra vascónica. Por otra parte, dicha dinastía representa la influencia franca o carolingia ${ }^{3}$, frente

1 A mi entender, no afecta a este planteamiento el hecho-que va imponiéndose con fuerza creciente en la historiograffa- de la considerable romanización del territorio vasco. A los argumentos arqueológicos, los principales, a favor de este proceso histórico, hay que añadir los deducidos a la toponimia, desarrollados especialmente por J. CARO BAROJA a partir de su obra Maleriales para una historia de la lengua vasca en relación con la latina, Salamanca, I946.

Recuérdese aqui, solamente, el dato, bien conocido por los especialistas, de que en el bronce de Ascoli (año 90 a. J. C.),entre los componentes de la Turma Salluitana figuren en mayoria vascones e ilergetes.

2 Para esta cuestión sigo fundamentalmente a J. M. LACARRA, Expediciones musulmanas contra Sancho Garcia, PV, I940, I, 63. Insiste en estas ideas enVasconia medieval. Filología e historia, San Sebastián, 1957, 59. Sánchez Albornoz, en la necesidad de decidirse, se inclina por esta solución.

s "El área occidental del Pirineo navarro, cuyos habitantes vivian aferrados a sus caserios de población reducida, pagana, por lo menos ell parte, y vascoparlaute, wo podia constituir el foco de irradiación de un reino cristiano. El impulso debió de llegar de la zona oriental, más romanizada, abierta a las corrientes ultrapirenaicas y cristianizadas, con gentes concentradas en villas y acostumbradas a desplazarse con sus ganados lejos de su tierra todos los inviernos.* A. J. MARTfN DUQUE, Los acerretanos en los orígenes del Reino de Pamplona. Miscelánea José Maria Lacarra, Zaragoza, 1968, 2 In29. 
a la autoridad anterior, más vascónica, de los Aristas y Velascos ${ }^{1}$, cambio político que no pudo dejar de repercutir en la lengua, como es obvio. $\mathrm{Y}$, en este aspecto, también han de influir sus relaciones con el Reino de León para solucionar los problemas comunes de defensa ante los árabes: la inteligeiacia con sus aliados requería el romance y no el vascuence.

Otras causas pueden alinearse junto a las anteriores en cuanto a la innovación idiomática. Ya quedó señalada la profunda romanización y cristianización del oriente navarro, afirmación basada en diversos hechos que deben ser brevemente recordados. Una de las conclusiones a que llega Menéndez Pidal ${ }^{2}$ al estudiar las vocales ibéricas en los topónimos pirenaicos es que uen las riberas navarras del río Aragón, a pesar de conservar el vascuence, hubo bilingüismo desde muy antiguo, efecto de la comunicación con Jaca»; también, que "fue en época primitiva románica una romanización débil o a medias, romanización bilingüe estacionaria en que convivieron durante siglos gentes vascongadas con gentes romanizadas, y de ahí la abundante conservación de topónimos vascos y su fuerte adaptación a la fonética romance» ${ }^{3}$. En efecto, basta echar una ojeada a la toponimia de la región que he señalado como cuna del romance navarro, para observar cómo los nombres vascos ofrecen la diptongación románica: Sangüesa, Javier, Lumbier, Navascués, Gallués, Narducis, etc.

En el año 848, San Eulogio de Córdoba ${ }^{4}$, según él mismo reficre, estuvo en Pamplona y visitó los monasterios de Leire, Cillas, Siresa, Igal (en el valle de Salazar) y Urdaspal (en el valle del Roncal), cuyo florecimiento encarece. De ese viaje recordará: "Cum essem olim in Pampilonensi oppido positus, et apud Legerense coenobium demorarer, volumina quae ibi erant, gratia dignoscendi, incomperta revolveremi 5 . De muchos de esos textos se llevó copias a su ciudad, donde eran desconocidos, como relata su biógrafo, Alvaro de Córdoba 6: "Inde secum

1 No falta quien sostenga que se trata de la misma dinastia. Asi, A. UBIETo La dinastfa Jimena. Saitabi, I960, 10, 65-79.

2 R. Mentendez PIDAL, Toponimia prerrománica hispana, Madrid, 1952, 42.

3. R. Mentendez Pidal, Origenes..., 462. En lo referente a restos arqueológicos, citaré únicamente la espléndida villa descubierta en la proximidad de Sangüesa. Cfr. B. TARACENA, La "villa" romana de Liédena, $P V$, I949, 10, 353-82; 1950, II, 9-39.

- S. EUIoGIo, Epistula III. Ad Wiliesindum Episcopum Pampilonensem. Migne, $P L, C X V, 846 a$.

- S. EuLogio, Liber apologeticus Martyrum, I 5. Ibid., 859a.

- alvaro DE cordoba, Vita vel Passio Sancti Eulogii, III, 9. Ibid., 7 I ib. 
librum Civitatis Beatissimi Augustini, et Aeneidis Virgilii, sive Iuvenalis metricos itidem libros atque Flacci satyrata Poémata [continúa la relación] reportaviti. No es preciso entrar en pormenores para percibir que estas noticias resultan muy reveladoras del signo y nivel cultural de la zona en cuestión.

A la vista de los hechos apuntados -y podrian aportarse otros muchos análogos - se ha de concluir que la situación resultaba claramente propicia para la aparición del habla románica; y que Leire debió de jugar un papel de primera importancia en la formación y posterior difusión del romance navarro. De su actitud lingüistica diferencial son buena prueba ciertas alusiones que desde mediados del siglo $\mathrm{XI}$ aparecen con frecuencia en sus documentos; se trata de referencias tales como: dicebatur rustico vocabulo Ataburu; dicitur in basconea lingua Mussiturria; bascones vocant Ygurai; etcétera. Más concretamente, para juzgar la influencia lingüística que el monasterio de San Salvador de Leire hubo de ejercer, basta considerar la que ejerció en otras esferas, que serviría de cauce para aquélla. Valga detenerse a recordar cuál fue, en líneas generales, la función desempeñada por el famoso cenobio en los orígenes del Reino navarro. En el aspecto religioso, será suficiente decir que «a lo largo de la mayor parte del siglo xr el obispo de Iruña [Pamplona] era siempre abad nato de Leire" ${ }^{1}$ y que posteriormente seguirá manteniendo la misma estrecha vinculación. A fines del citado siglo, Leire tenía bajo su jurisdicción 72 monasterios y 57 villas 2 . En cuauto a las relaciones con el poder civil, Leire use ve favorecido continuamente por las donaciones de los reyes, que buscan allí su corte y su sepultura. Los obispos de Pamplona tienen alli su sede y salen de sus claustros. Es el centro cultural más importante de Navarra» ${ }^{3}$.

A los Jimenos, a las diversas circunstancias sociales y culturales que los acompañan, hay que atribuir, a mi parecer, en buena medida, el comienzo de un nuevo romance en las márgenes del Aragón $y$, posteriormente, en la cuenca de Pamplona y en la tierra de Estella. Con palabras de Menéndez Pidal 4: "El Reino de Navarra, desde su comienzo en el siglo $\mathrm{x}$, usó promiscuamente dos lenguas habladas, el vasco y el dialecto navarro, afín al castellano, y como lengua escrita sólo usó el

1 A. UBIETO, La introducción del rito romano en Aragón y Navarra. HS, I948, I, 302 .

2 J. GoÑI GazTanmide, Los obispos de Pamplona del siglo XII. Anthologia Annua, 1965, 13, 294.

- C. Corona, Los abades del monasterio de San Salvador de Leire. Pir, I948, 4,478 .

- R. Mrontendez Pidal, España y si6 historia, Madrid, I957, I, 83. 
NAVARRA EN LOS SIGLOS VIII - IX

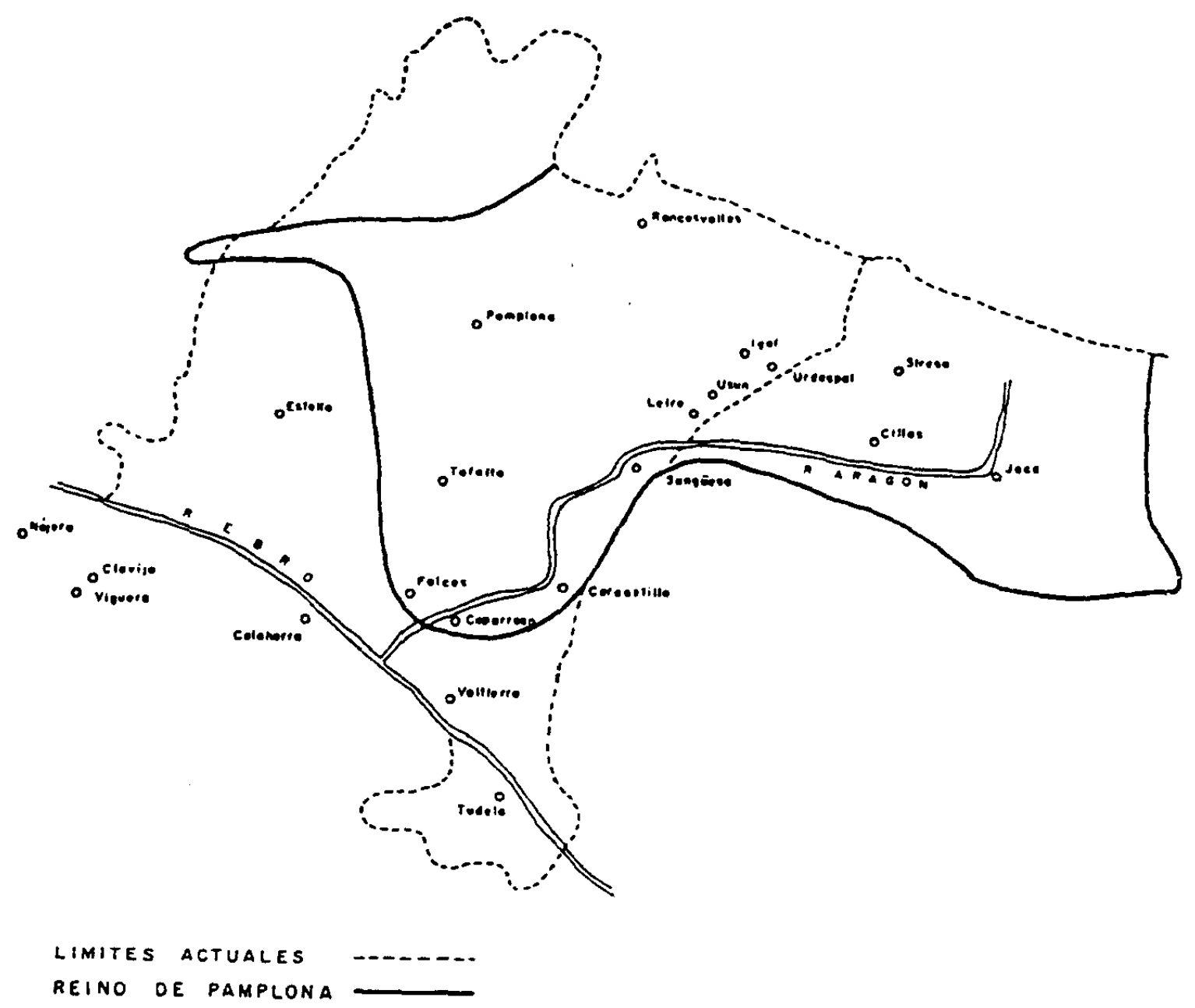


LIMITES MAXIMOS DE LAS POSESIONES DE SANCHO EL MAYOR $(1.005 \cdot 1.035)$.

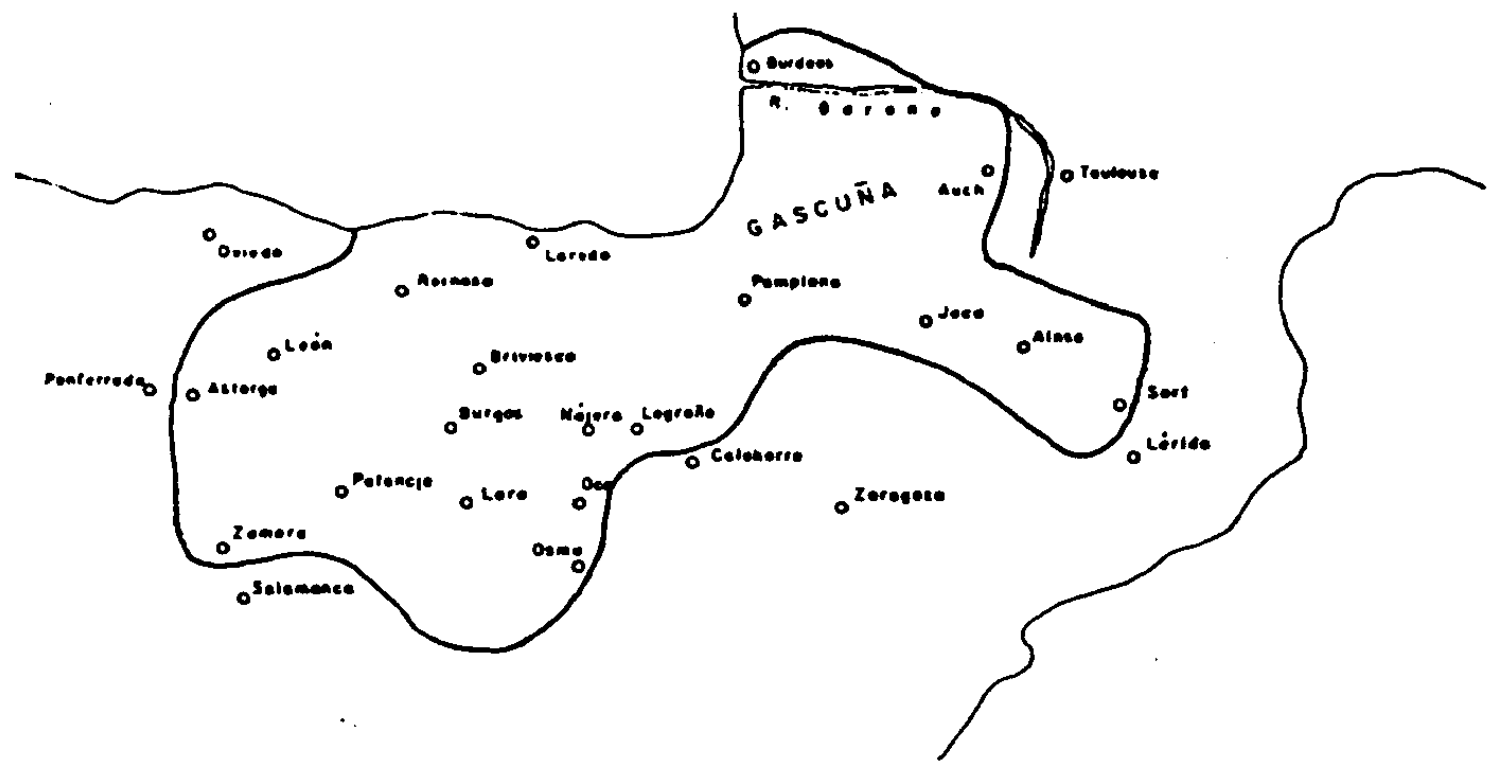


latín y el dialecto románico, pues el vasco no comenzó a escribirse algo sino en el siglo XvIn.

Iil hecho de que la aludida zona navarra estuviera todavia a fines del siglo XVI ${ }^{1}$ dentro de la frontera del vascuence, parece contradecir la afirmación de ser ella la originaria del romance navarro. Encuentro una explicación satisfactoria, a mi juicio, para resolver esa dificultad: el romance va muy ligado, inicialmente, a la corte, al ámbito oficial del Reino, nada estable, por cierto. De ahí que se desplace con él hacia I’amplona, Esstella, Olite, etc., y no logre arraigar en aquella área originaria 2; como no arraiga inicialmente en toda la verticalidad social de ninguna zona, ya que el romance constituye la lengua de un grupo antes que la de una región. Ni siquiera en Pamplona y sus aledaños triunfó el romance lasta tiempos muy recientes (cfr. $\$ \S 6$ y 9 ).

\section{Difusion del romance navarro}

I,a difusión geográfica y social del romance navarro plantea una problennatica específica - si bien análoga a la que se ha visto respecto de su origen- dentro del ámbito iberorrománico, puesto que ch ambas direcciones tropieza con un medio lingüístico heterogéneo, el vascuence, más extcnso y más compacto. I a explicación de su triunfo se encuentra, en mi opinión, en estas palabras de Nichelena 3: "Eil reino de Nararra, la creación política más importante de Vasconia, siguiendo como no podía menos el uso general de Occidente, empleó el latín como única lengua escrita. Más adelante, cuando éste empezó a dejar paso en todas partes a las lenguas vulgares, se recurrió al romance $y$ no a la «lingua Navarrorum» o "basconea lingua» de los documentos. No es difícil ver por qué. Iil romance era la lengua exclusiva de algunos navarros y otros lo conocían; al ejemplo de los países vecinos y su misma proximidad al latín facilitaba su uso escrito. Nacla favorecía al vascuence, lengua aislada y sin cultivo literario, a no ser la presencia de una masa de individuos unilingües, que debemos suponer muy crecida en algunas regiones. Por desgracia, no formaban parte de los grupos más influycutes del país".

$A$ esta resistencia del vascuence, no ya al cultivo literario, sino a la simple perduración por medio de la escritura al servicio de las necesi-

1 Cfr. M. DE LEcuona, El eushera en Navarra a fines del XVI. RIEV, I933, 24. 365-74.

- Sin culbargo, cfr. $\S 8$.

I. Micmiliens, Historia de la literatura vasca, Madrid, Ig60, I2. 
dades cotidianas, hay que atribuir el hecho de que el romance navarro se convirtiese en lengua del derecho público y del derecho privado, es decir, de todo el ámbito documental. Conquistada desde el primer momento, sin resistencia conocida ${ }^{1}$, esa privilegiada posición, puede decirse que la suerte estaba ya irrevocablemente decidida.

Si se atiende a la consideración geográfica, ha de pensarse que hasta el rincón del reino más apartado de la corte llegaba de ese modo el influjo lingüístico romance; desde el punto de vista social, su conocimiento resultaba indispensable para todo habitante del reino de Navarra que no quisiera quedar marginado, es decir, para las clases más altas de la sociedad, para los dirigentes de ella.

Esta última circunstancia no puede considerarse como operante sólo en el plano individual, sino que también hubo de influir corporativamente a favor del uso del romance. El reino de Navarra tuvo relaciones politicas, desde muy temprano, no sólo con el de Aragón, sino con el de I,cón y también con Castilla. Como anteriormente hice notar, el empleo del vascuence liubiera constituido un grave impedimento para la comunicación y el entendimiento con los restantes grupos cristianos de la Península. He aquí otro motivo para preterirlo al romance autóctono.

También Lacarra ha buscado una explicación para la propagación de este romance, la cual viene a reforzar las expuestas anteriormente. Coteja Lacarra ${ }^{2}$ la situación de Navarra con la de Inglaterra, donde «e! latín era tan sólo una lengua escrita, no hablada; era una lengua de clérigos y eruditos [...] Por influencia de la corte, de las clases dirigentes que sólo hablaban su lengua nacional, se recogen sus gestas o se traducen libros. Pero nada de esto se daba en el País Vasco: ni hay una liturgia en vascuence, ni una corte o unos elementos directivos totalmente ajenos al latín. De aquí que no se sienta en la corte una necesidad absoluta de redactar los documentos en una lengua nueva con la adaptación correspondiente, cuando ya disponian del latín o del romance, inteligible para una buena parte de los súbditos del reino. Piénsese que cuando en el siglo $\mathrm{x}$ se estabiliza la monarquía navarra, ésta se extendía desde Jaca hasta la Rioja, y que precisamente la dinastia Jimena procede de la zona más romanizada del País».

A juzgar por lo que se conoce de las diferentes fases de la regresión

1 No parece que llegara a tencr realidad una supuesta traducciọ́ al vascuence del Fuero general de Navarra. Cir. p. 49, nota 2.

2 J. M. LACAkRA, Vasconia..., I4. 
del vascuence en Navarra ${ }^{1}$, cuesta trabajo admitir la afirmación de Tovar 2: "Debe ser la fundación de la ciudad de Panplona la determimante de la pérdida del vasco en las zonas llanas de Navarra". Por ello cstimo más acertado el juicio de Menéndez Pidal ${ }^{3}$, formulado con antcrioridad a aquella afirmación: "La ciudad de Pompelone, Pamplona, no tuvo fuerza para irradiar romanidad, sino apenas para abrigarla en sus calles y en sus arrabales, como un islote rodeado de población de lengua vascónica; la penetración del romance en esta zona es tardía [...], posterior a la diptongación de $e$ y $o$, por lo cual en su toponimia se conservan sin diptongar nombres como Baigorri ('río rojo') e Iriberri ('pueblo nuevo')». No fue, en efecto, la ciudad de Pamplona el centro de irradiación del romance navarro, pues ni siquiera era éste común a todos los estamentos sociales ciudadanos. Casi hasta los tiempos actuales se ha hablado con intensidad la lengua vasca en Pamplona 4 . Por eso, estando plenamente de acuerdo con la anterior aseveración de Menénde\% Iidal, que él reitera en distinta ucasión 6: "Pamplona tuvo nuy poca eficacia como centro romanizadorn, discrepo, en cambio, de esta otra: "La ciudad de Pamplona, que en medio de este territorio vasco forma un islote donde sólo se habla romance» ${ }^{6}$. Se hace necesario aminorar considerablemente esta última afirmación ante la ya aludida perduración del vascuence en Pamplona durante los últimos siglos; en cuanto a la época medieval, baste aportar aquí un testimonio árabe: según el

1 He recogido un amplio caudal de datos y noticias sobre esta cuestión en mi estudio Vascuence $y$ romance en la historia lingizistica de Navarra.

2 A. 'Oovar, Sobre la primitiva extensión del vasco, en El euskera y sus parientes. Madrid, 1959, 89. Este estudio apareció primero con el titulo de Los Pirineos y las lenguas prelatinas de España, en las Actas del I Congreso Inlernacional de Estudios Pircnaicos, Zaragoza, 1952, 149-52.

En cambio, los hechos le dan la razón cuaudo asegura que edebió de ser la romanización la que borrara la lengua vasca en las zonas pirenaicas centrales. Lis muy posible que la elección por Sertorio de Huesca como capital cultural sea la responsable inicial ciel retroceso del vascuence en esta parte».

3 R. Minéndez PIDAL, Origenes..., 463.

- Numerosos testimonios probatorios en mi citado estudio, Vascuence y romance... Cfr. también el $\S 9$ del presente. En el mismo sentido, el fuerte sabor euskera de la toponimia del término de Pamplona, y aun la urbana, como puede verse en I. BALEzTENA, Toponimia del término de Pamplona, en Actas de la primera reunión de toponimia pirennica, Zaragoza, 1949, 59-63, y en E. MLARTINEZ DE LECEA, Noticia sobre los antiguos barrios $y$ de algunas calles $y$ términos de la ciudad de Pamplona, Pamplona, I965.

- R. MI:NENDIZ I'IDAL, Toponimia..., 43.

- I lid., 38. 
repertorio históricogeográfico Kitab ar-Rawd al-mi'tar (siglo xIv; basado en fuentes mucho más antiguas), Pamplona "se encuentra en medio de altas montañas y valles profundos, está poco favorecida por la naturaleza. Sus habitantes son pobres, no comen según sus deseos, y se cintregan al bandolerismo. I, a mayor parte hablan el vasco, lo que les hace incomprensibles") ${ }^{1}$.

Respecto de las relaciones del romance navarro con el occitano de los diversos núcleos burgueses, la cuestión aparece más sencilla. E1 occitano se mantenía por su enquistamiento en un medio lingüístico irreductible, el vascuence. En cuanto entró en contacto con otro romaulce que gozaba de mayor relieve social, estaba abocado a difuminarse en él, como efectivamente sucedió ${ }^{2}$.

La difusión del romance navarro arranca de la corte, se encuentre donde se encuentre ésta, a través de sus disposiciones legales escritas. Las más de las veces, emitidas, sí, desde Pamplona, pero también desde Sangücsa, Olite, 'Tafalla, Puente la Reina ${ }^{3}$, Estclla, ctc.

I a atención a este proceso de difusión del romance - desde arriba, socialmente- proporciona, a mi parecer, una nueva visión de los móviles cleterminantes de la regresión del vascuence. Tal como suele tratarse esta cuestión, uno se forja la imagen de que la presión progresiva del romance, desde la periferia, constituyó la causa del retroceso de la lengua vasca. Esto resulta, dentro del modo figurado de la expresión, verdad; pero sólo parte de la verdad. Pues si aquella presión pudo ejercerse fue, al menos parcialmente, gracias al debilitamiento, social más que geográfico, del uso del vascuence que la difusión del romance autóctono producia en el interior del área territorial lingüisticamente vasca. Es decir, que, según yo entiendo, en el crecimiento del romance no hay que contemplar tan solamente un fenómeno de regresión del vascuence

1 i. J. M.AR'Tí DUQUE, Aragón y Navarra seguin cl "Litab ar-Rawd al-mi"lar». Arg, 1956, 7, 252. Posteriormente la sido traducida la obra árabe por M. P. Maestro, Valcncia, Ig63.

2 Me ocupo con detalle de esta cuestión en mi estudio La lengua occitana en Naiarra.

- Alguna vez se ha citado a Puente la Reina como foco de irradiación romance; nada más lógico que pensar así, puesto que en la población confluyen dos ramas del camino de Santiago. Sin embargo, la realidad sociolingüistica debia de ser muy distinta, a juzgar por diversas noticias (recogidas en mi estudio Vascucnce $y$ romance...), que muestran el arraigo de la lengua vasca entre la población indigena liasta el siglo pasado, y por los diversos datos conocidos sobre la frontera de aquella lengua en Navarra. Aquí simplemente recordaré que en 1820 todavía liabia alyún vecino que sólo entendía vascuence. 
por reducción de sus límites geográficos, sino también un proceso de expansión interior, dentro de esos límites, desde un centro inmorador: la monarquía, la cancillería regia.

$\Lambda$ dilerencia de lo que ocurre con la conservación del vascucnce en el territorio lingüísticamente románico, faltan noticias y datos específicos - salvo de época recicnte- sobre la introducción o presencia de manifestaciones concretas del romance navarro en el interior del ámbito vascohablante, si se prescinde de lo que supone globalmente la docunnentación escrita. De modo que sólo puedo ofrecer unas escasas referencias de la época medieval para añadir a la recién citada del Kitab $a r-R a w d$, que denuncia la existencia en Pamplona de una minoría lingüística no vasca. La primera de ellas, las cliversas glosas, de las que sólo recordaré aquí la equivalencia Aker çaldua $=$ soto de ueko, que se encuentra, aislada, en un documento latino (I074) de Sancho de Peñalén, para aclarar el topónimo vasco. Otro dato: en el manuscrito de la Bibliuteca Nacional de Madrid que contiene la versión latina de los lúcros de Aragón, una nota marginal, del siglo $x \mathrm{v}$, informa acerca de la palabra ayec de este modo: "nnota quod hoc verbum utilur I'ampilone vulgariler ab agriculloribus" ${ }^{1}$. Indudablemente, en la citada época los agricultores de Pamplona eran vascohablantes, pero empleaban, como se informa, una interjección romance o trasmitida a través del romance ${ }^{2}$. Por último, la denominación de Romanzado que lleva un valle de la merindad de Sangüesa parece apuntar - por razón misma del nombre- la existencia de un núcleo románico en territorio vascohablante. Volveré más adelante $(\S 8)$ sobre la problemática caracterización lingüística de este territorio, para no entorpecer ahora la exposición.

Independientemente de la importancia que se conceda a uno $\mathrm{u}$ otro factor - $\epsilon 1$ interno y el externo- en la sustitución del vascuence por el romance, se llega a la conclusión, al observar el proceso, de que en él operan - como se va a exponer a continuación- dos romances diversos; más exactamente, dos áreas romances territorialmente diversas, sin solución de continuidad geográfica (sí social) entre ellas, aunque deban identificarse lingǘsticamente, ya que se trata de la lengua oficial de la misma entidad política, 'el reino de Navarra.

En efecto, al norte (y al este) de la frontera medieval vascorrománica de dicho reino, autóctonos en territorio lingüísticamente vasco, se

1 G. T⿱丷I,ANDER, Ayec. RFE, 1936, 22, 193-7.

2 Para Tilander, ayec procede de *a d e c $c$ u m, wientras que para STEIGER, $R F E, 195 I, 35,341-4$, es de origen arábigoespañol. 
localizan desde época temprana, como ya se vio ( $\$$ 5), núcleos románicos que se denuncian como tales - si no bastara la lengua de sus documentos- por sus alusiones del tipo in basconea lingua dicitur para citar determinados topónimos. Listos núcleos del NE navarro, que pueden identificarse inicialmente con los monasterios y con la corte real ( $\$ 5$ ), son los que difunden su romance por la zona media de Navarra, según la linea Sangüesa, Pamplona, Irache, a medida que avanza la reconquista. Es la modalidad lingüistica que irradia desde la cancillería regia, en una dimensión nıás social que espacial.

Al sur ( $\mathrm{y}$ al este) de la mencionada frontera existe otra área románica que, naturalmente, se va extendiendo a medida que retrocede el área geográfica del vascuence (lo cual también puede interpretarse como que éste se retira ante el avance de aquélla), cuyo ámbito territorial pasa a ocupar. Conocida la fundamental identidad lingüística existente entre Aragón y la Rioja oriental y dada la situación, respecto de ambas regiones, en que se encuentra la zona meridional de Navarra (es decir, del territorio navarro no vascoliablante, al menos desde los comienzos de la Elad MIedia), ha de pensarse que el habla de esa zona debía coincidir con la de aquéllas, con las que forma una unidad natural, un largo tramo del valle del Ebro, que va desde la Rioja hasta Zaragoza. Baste recordar aquí 10 antes dicho $(\$ 4)$ a propósito de las Glosas emilianenses $y$, respecto de la situación actual, remitir al final del $\S 7$. No resulta, pues, admisible suponer que por la periferia el vascuence haya sido sustituido, .como suele explicarse, por el castellano (salvo en tiempos modernos), sino por un romance que ha de identificarse con el aragonés. Debo decir que aqui tomo este término, aragonés, por motivos de claridad, en cuanto que designa una variedad lingüística de fisonomía bien conocida; pero a sabiendas de que se trata de una realidad idiomática, que también podría denominarse riojano (de modo incidental, Y. Malkiel, Paradigmatic resistance..., 287 y 295, considera decididamente al riojano antiguo como a western outpost of Navarrese... Riojan, i. e., essentially Navarrese. Pero, a propósito de la lengua del ms. I de Berceo, does not seem entirely Navarrese) o navarro, común a la ribera de un tramo del Ebro. Bien entendido que la influencia lingüística castellana se ejerceria temprano sobre el navarro (cfr. § Io), como sobre los restantes dialectos peninsulares, puede, pues, afirmarse de modo general que, hasta que el castellano no obtuvo decididamente la hegemonía lingüística peninsular, la modalidad románica que competía con el vascuence era de características aragonesas. $\mathrm{Y}$ que aun después de alcanzada aquella hegemonía, el habla aragonesa (entendida aquí en sentido estricto y en la medida en que conservó su fisonomía), más 
persistente que el habla navarra, tuvo que seguir influyendo sobre el territorio navarro en su condición de adstrato.

Así pues, resulta indudable que era de rasgos semejantes a los del aragonés el romance que desde la periferia iba erosionando el territorio vascohablante de Navarra en época medieval. Ahora bien, el romance autóctono navarro que se fue extendiendo en dirección oeste y se convirtió en la lengua oficial del reino, procede del rincón subpirenaico del noreste donde comenzó la reconquista navarra (al menos, donde se encontraban sus realizadores en el siglo $\mathrm{x}$ ), es decir, de un territorio contiguo, si no común, a núcleos originarios del reino de Aragón. Lo que lleva a suponer, valga adelantarlo, su fundamental semejanza idiomática.

Hay que recordar aquí que Navarra y Aragón, en unidad geográfica, fueron una sola enticlad política en varios momentos de su historia tcmprana, especialmente en el período I076-II34. İn el orden eclesiástico, debe contarse con que en el siglo ix ula jurisdicción del obispo de l'amplona llegaba a todas las tierras occidentales de lo que después scría el reino de Aragón, incluyendo posiblemente el valle de Hecho" ${ }^{1}$ y pusteriormente se amplía, llegando a incluir las Cinco Villas aragonesas, hasta el Gállego. Esta misma comunidad se revela también en el terreno de los hechos particulares, de los que citaré algunos de los muchos que podrian aportarse.

Se ha hablado antes $(\$ 5)$ de la influencia lingüística del monasterio de Leire. Pues bien, Leire estaba en la frontera de ambos reinos, hasta el punto de que en el últino tercio del siglo xir se lo disputaban Aragón y Navarra: "Aunque la abadía estaba situada dentro del territorio navarro, era más aragonesa que navarra, más, quizá, que en tiempos de García el restaurador. 'Tan aragonesa, que Alfonso II la consideraba como uno de tantos monasterios de su reino' ${ }^{2}$ (con este motivo, Alejandro III lo tomó bajo su protección en II74). Al monasterio de Leire se trasladan en el año 842 , desde Huesca, las reliquias de las santas Nunila y Alodia; en él recibieron floreciente culto durante diez siglos ${ }^{3}$. Bajo Alfonso I - por citar un último caso- navarros y vascones intervinieron en el asedio de Zaragoza: "obsedit Cesaraugusiam cum suis naluralibus Aragonum et Navarre, et cum Centone de Bearn et Uasconi-

1 A. UBIETo, Las diócesis navarro-aragonesas durante los siglos $I X$ y $X$. Pir, 1954, Ia, 183.

2 J. GoÑ Gaztanimini, Los obispos de Pamplona del siglo XII..., 293.

3 C. M. Lórrz, Apunles para una historia de Leire. PV, I964, 25, 139-68. 
busi" ${ }^{1}$, según refiere la crónica pinarense, estableciendo una distinción étnica que con seguridad es también lingüística.

La consideración de todas estas circunstancias comunitarias, entre las muchas que podrian aducirse, lleva a pensar que el romance del este navarro y el de oeste aragonés tuvieron que constituir necesariamente, en sus orígenes, una misma modalidad idiomática. En mi opinión, el estadio lingüístico del Liber Regum debe considerarse como. una buena muestra de tal modalidad, de manera que las alternantes atribuciones historiográficas de dicho texto al ámbito navarro o al aragonés carecen probablemente de sentido, al menos lingüísticamente ${ }^{2}$.

Esta comunidad inicial del habla de Navarra y Aragón queda confirmada, en alguna medida, por los resultados de las encuestas realizadas en época actual (cfr. $\S 7$, final).

\section{La unidad lingiiistica navarroaragonesa}

De los antecedentes expuestos puede concluirse la esencial identidad originaria entre el romance navarro y el aragonés, puesto que la invasión lingüistica que en Navarra progresaba según la dirección este-oeste era originarianente la misma que seguía en Aragón una dirección norte-sur, para luego incidir en Navarra en sentido sur-norte y oeste-este ${ }^{3}$.

Una conciencia tradicional de esa identidad es probablemente la que ha acuñado el término navarroaragonés, cuyo uso quedó antes (§ 2) documentado. El habla románica de Navarra, a juzgar por el proceso de su formación, ha de coincidir con la de Aragón. Ahora bien, así como para hablar de la primera apenas se utiliza la denominación

- Crónica de San Juan de la Peña. Ed. de A. UbIrTo, Valencia, 196r, 70.

2 L. COOPER, El Liber Regum. Estudio lingüitstico, Zaragoza, I960 (reseñas: J. M. Isope Blanch, $N R F H, 196 n, 14,384-5$; P. M. I.loyd, $H R$, 1964, 32, 262-3).

Para Cooper, último editor y estudioso del texto, ula lengua del Liber Regum es aragonesa o uavarra" (9); "debido a la semejanza entre el navarro y el alto aragoués, es dificil afirmar con certeza cu cuál de los dos está escrito cl Liber Regum, aunque por varias razones nos inclinamos a creer que está en el primeron (II).

3 Prescindo aqui, por no afectar directamente al caso, de la consideración de la modalidad subsistente aún en los valles norteños aragoneses, no en los navarros, con fisonomia propia, que ha pernitido acuñar la denominación de pien aico. 
de navarro, romance navarro, dialecto navarro, etc., sino que se prefiere el compuesto citado, para la segunda, aunque a veces se utilice el compuesto, resulta más general la denominación simple de aragonés. En rigor, pues, la denominación debería ser la misma, tanto en un caso como en otro. Si así, manifiestamente, no ocurre, se debe, sin duda, a dos razones.

Primeramente, la mayor persistencia en Aragón, frente a Navarra, de sus rasgos lingüísticos diferenciales respecto del castellano (cfr. § IO); añádase la diferencia en extensión territorial y en cultivo literario, abiertamente en favor de Aragón.

Lìn segundo lugar, la mayor y más temprana atención de los estudiosos y eruditos de Aragón (también en esto en fucrte contraste con $\mathrm{Na}$ varra) hacia su romance originario; el afán de aquéllos por ennoblecer sus origenes frente al castellano, por realzar su antigüedad y pureza, ctc. ${ }^{1}$, frente a la indiferencia o desconocimiento de los navarros ( $\$ 2$ ).

Diclıo de otro modo, la desateinción hacia el estudio de las peculiaridades lingïisticas de Navarra ha determinado que se encuadren, al observar, sobre un material muy reducido, su coincidencia con las aragonesas, bajo el nombre de éstas.

He hablado, pocas líneas atrás, de conciencia de la identidad del habla de Navarra con la de Aragón porque falta todavía (cfr. § 3) una base cientifica sobre la que justificar tal identidad. Iin efecto, opino que se ha hecho aquí por primera vez la observación comparada del desarrollo histórico y geográfico del romance de ambas regiones. $\mathrm{Y}$ en cuanto al cotejo directo de los rasgos lingüísticos de una y otra, es muy escaso lo que se ha realizado, a causa de la penuria, tantas veces mencionada, de estudios particulares en el ámbito navarro.

Anteriormente cité ( $(2)$ la afirmación de Amado Alonso ${ }^{2}$ de que el navarro conservaba el grupo $m b$, lo que supondría un rasgo diferencial respecto del aragonés. Recogeré ahora el resultado de otras investigaciones de este orden.

Con tal finalidad explícita estudió Ynduráin ${ }^{3}$ el Fuero general de Navarra, según él mismo declara: "El presente trabajo se ha emprendido con el propósito de ver hásta qué punto pudiera distinguirse, dentro de

1 Cif. I. MONGF, Nolas..., artículo dedicado fundamentalmente a historiar esta cuestión.

2 No justifica A. Alonso su afirmación, que requeriria una detenida comprobación documental.

3 I. YNDURÁIN, Contribución..., 9. 
la unidad dialectal navarro-aragonesa, algunas peculiaridades más propiamente navarras». Como resultado de su investigación cita "algunos rasgos peculiares navarros, tales como los grupos coa, goa; el resultado del grupo romance $d^{\prime} c$, que en los ms. de la Cámara de Comptos es $\mathrm{rg}$; la evolución de $x$ y de scy en los mismos ms.; el tratamiento de $m^{\prime} n$; la grafía de $l$ y $n ;$ y algunos otros de menor importancian. Ilega así a la conclusión de que, si bien "dentro de esa unidad lingǘstica hay que reconocer alguna personalidad al navarro antiguo", "por ahora y con los datos que proporciona el Fuero, sigue en pie la unidad lingüística navarro-aragonesal' 1.

Al recoger esa conclusión, señala Alvar ${ }^{2}$ que «sin embargo, ell el uso de las grafías, cada una de las regiones se caracteriza por cierta personalidad». También apunta, tras la consideración de las fuerzas lingüísticas actuantes en Navarra, que en esta región se pierde la - $d-$ intervocálica, mientras que en Aragón se conserva, aunque "hacen falta investigaciones más minuciosas» ${ }^{3}$ para garantizar este aserto. En una obra posterior ${ }^{4}$ reafirma la identidad lingüística de ambas regiones: "Uno Navarra con Aragón, a pesar de las discrepancias que yo mismo he señalado alguna vez. No son, sin embargo, tan importantes que deban obligar a la fragmentación dialectal».

I.1 intento más completo que conozco "para establecer una distinción entre el navarro y el aragonés" se debe a Gifford y Hodcroft ${ }^{5}$. Recogen estos autores todos los datos obtenidos por sus predecesores en tal empresa y los documentan con los materiales de su antología; de éstos deducen también otros rasgos diferenciadores, aunque advirtiendo que la limitación del repertorio textual con que cuentan no permite "poder sacar de él conclusiones firmes». Tales rasgos son los siguientes: mayor duración de los posesivos to, so en Aragón; grupo nominal de artículo + sustantivo + posesivo, existente en los textos aragoneses, pero no en los navarros; coordinación adverbial del tipo legitimament et solempne, propia del aragonés, desconocida en navarro ${ }^{6}$; mayor

1 Ibid., 9 I.

2 M. AI,var, El dialecto..., 43. Al mismo tiempo, en Pir, 1953, 9, 59, afima más rotundamente: "Hay bastante discrepancia en los criterios gráficos seguidos por los escribas de Navarra y Aragón; lejos, al menos en esto, la pretendida unidad dialectal de ambos reinoso.

s Ibid., íz".

- MI. Al, VAR, Textos hispánicos dialectales, Madrid, Ig60, I, XVII.

5 D. J. GIFroRd y li. IV. HODCROFT, Texlos lingiiisticos del medievo español, Oxford, I959.

- Sin embargo, una rápida búsqueda en los textos y colecciones documentales citados en $\S 4$, me permite apintar varios testimonios navarros que ofrecen 
frecuencia en aragonés del imperfecto en $-i c-y$ de los derivados de in $\mathrm{de}^{1}$.

Esta idea de la unidad lingüística de Navarra y Aragón no se con-: firma, antes bien parece descartarse, por el primer texto, según mis conocimientos, ell que se confronta, multilateralmente, el habla de ambas regiones. Ėn su Diálogo de la lengua, explica Juan de Valdés 2: "Como la lengua castellana se habla no solamente por toda Castilla, pero cn el reino de Aragón, en el de Murcia con toda el Andaluzia y' en Galizia, Aslurias y Navarra, y esto aun entre la gente vulgar, porque entre la gente noble tanto bien se habla en todo el resto de Spaña, cada provincia tiene sus vocablos propios y sus maneras de dezir, y es assi que el aragonés tiene unos vocablos propios y unas propias mancras de dczir, $y$ cl andaluz tiene otros $y$ otras, $y$ el navarro otros $y$ otras, $y$ aun ay otros $y$ otras en Tierra de Campos, que llaman Castilla la Viejal. Este pasaje parece denunciar, ya en su enunciación doctrinal, una marcada diferenciación; si además se consideran los otros contrastes propuestos (aragonés, castellano viejo y andaluz), queda ratificada la impresión de una diferencia acusada. Pero ninguna otra opinión de este signo aparece en la bibliografía posterior.

Hasta varios siglos después no vuelvo a encontrar nueva documentación sobre el tema. Aliora es Borao ${ }^{3}$ quien afirma que antes y después de la formación de su Diccionario recorrió Navarra y que halló "tan

la misnua disposición sintáctica: avisadament e vigurosa (I'rincipe de Viana, Cronica, 1451); pacificament e sosegacla (ibid. Muclios otros ejeiuplos cn este texto); expressamente y estrecha (Pamplona, $x_{4} 69$ ); directamente ni indirecta (Pamplona, I490). Como puede observarse, todos los casos citados pertenecen al siglo xr; no he encontrado ninguno de siglos anteriores, en los que la fórnula más general parcce ser: dreitament et lealment, incluso se documenta saluament, francament et quitament (Estella, I 360 ).

1 Sin poner en duda la anterior afimmación, no puede, sin embargo, decirse, en wi opinión, que los derivados de $\mathrm{i}$ u d e son unuy raros en los textos navarros. Una ligera indagación me depara numerosísimos ejemplos, con variedad de forunas y de funciones. He aquí algunos, prescindiendo de todos los del Liber Regum, donde resultan especialmente frecucites: que end fuesse tul traidor que non s' end podiesse saluar (I22I); por fer end toda vostra propia voluntat (12.5S); jutrólo por muestro mandamiento e fueron ne pagados (Sangüesa, I268); so end de manifiesto (1295); uos aseguredes dcll en manera que uos en podades fazer dreyto (Leire, I300); los que lo oian, s' en goarden (Villafranca, h. I340); es cnde apropiada la dicla eglesia (...) Non hend y a ninguno (1353); los ende envestimos (Damplona, 1385); non ayan a ser en el conseillo (...) antes en sean excludidos (Pamplona, I4 I2); inna isla chica que clencla está (1454, l'ríncipe de Viana, Crónica).

2 J. DI: Vir.dís, Diálogo de la lengua. Id. de J. Montfsinos, Madrid, 1946, 35.

3 J. BORAO, Diccionario..., 70. 
idéntico con el de Aragón el dialecto familiar, como que apenas hay palabra o frase que no les sea perfectamente común». Es ésta la primera afirmación justificada por un cotejo que encuentro sobre la igualdad idionática de ambas regiones, bien entendido que en lo referente a la época del autor (recuérdese cómo, por el contrario, en el prólogo de la segunda edición de la obra citada, debido a F. Sancho y Gil, se registraba el uso más decidido de navarro y romance navarro, aplicado a la época medieval).

La tesis de Borao recibe una sorprendente confirmación de detalle, con anticipación de un siglo, en dos testimonios ocasionales. A mediados del siglo xviri, el Padre Isla ${ }^{1}$ recoge dos voces como caracteristicas de Navarra. Una, estremar, que explica de este modo: "asi se llama en Navarra al barrer, regar, limpiar las sillas y cubrir las camas" ${ }^{2}$. La otra palabra es universidad, sobre la que escribe: "Tiene este reino briareo el brazo que se dice de las universidades. Llámanse asi todas las repriblicas que logran voto en Cortes. Universidad [...] quiere decir lo mismo que comunidad o cuerpo que representa el comin (y eslo es lo que significa en el vocabulario politico navarro la palabra universidad). Pues bien, resulta interesante comprobar la coincidencia, en ambos casos, con el Diccionario de Borao: extremar limpiar la casa; principalmente asear los pisos'; universidades 'además de las usuales acepciones, se halla alguna vez en sentido de ciudades; y la verdad es que el brazo de las universidades se componía de representantes de los pueblos de voto en Cortes, que cran en general ciudades'.

También los estudios modernos sobre el habla viva ratifican la afirmación antes citada de Borao, favorable a la identidad lingüística de Navarra y Aragón. Al estudiar el habla de Oroz-Betelu llega Alvar ${ }^{3}$ a la conclusión de que "la presión aragonesa es muy fuerte en esta zona $o$, al menos, el antiguo dialecto navarro-aragonés continúa hoy teniendo la unidad lingǘstica que señalan los textos medievales». Igualmente, a propósito de la zona de Aézcoa ${ }^{4}$, insiste en la misma idea; tras señalar que lo nismo que en Oroz-Betelu hay un caudal extraordinario de aragonesismos", precisa que "las palabras que figuran en glosarios aragoneses no las consideramos como tales aragonesismos, sino que, en parte,

1 J. F. DE ISLA, Trinnfo del amor $y$ de la leallad. Dia grande de Navarra, Madrid, s. a., segunda reimpresion.

2 La recoge Iribarren en su Vocabulario navarro y sigue usándose en Navarra en la conversación ordinaria, anuncios periodłsticos, etc., especialmente el sustantivo extremadora 'mujer de la limpieza'.

3 M. Alvar, El habla de Oroz-Betelu. RDTP, 1947, 3, 470.

- Mr. Arvar, Palabras y cosas en la Aézcoa. Pir, 1947, 3, 36. 
creemos que debe tratarse de la antigua unidad lingüística del dialecto navarro-aragonés, unidad existente en los testimonios navarros medievales y que ha pervivido modernamenten. Como prueba de esta comunidad, puede citarse también la situación del valle del Esca, donde, basada en la geografia, "se deja sentir notoriamente la impronta navarran, aunque la influencia ha de ser tardía, pues la zona navarra fue vascohablante hasta el siglo pasado ${ }^{2}$.

En la zona sur del dominio, variantes comunes de la pronunciación del grupo ir se extienden desde Alava hasta Zaragoza, a través de Logroño y Navarra ${ }^{2}$. Esta tiene en común con la Rioja "la inacentuación de los adjetivos demostrativos", según Navarro Tomás ${ }^{3}$. Por último, cl rasgo más característico del aragonés para el propio Navarro Tomás 4 "el tono relativamente alto con que de ordinario terminan las frases", se encuentra también, según él, en Vasconia y Navarra 5.

lirente a todos los anteriores testimonios, favorables a la unidad, están atestiguadas algunas discrepancias, aparentemente leves, pero que pudieran suponer una diferenciación más profunda. I.os pueblos navarros de los valles de Salazar y Roncal ofrecen ' logaril 'hogar', micntras que Salvatierra y Sigüés, a la entrada natural del valle de Roncal, pero pertenecientes a Zaragoza, presentan fogaril, igual que los de la zona de Huesca. Alvar concluye de estos datos que Aragón "ha manteniclo una fonética de carácter arcaizante, mientras que Navarra ha sustituido la $f$-aragonesa por una $h$ - castellana». Pero cabe preguntarse si tal divergencia no responderá a una evolución autóctona; si 110 scrá indicio del distinto resultado original de $f-$, independientemente de la castellanización, es decir, de la acción del superestrato. Estimo

1 MI. ALVAR, Notas lingiïsticas sobre Salvatierra y Sigïes (Valle del Esca, Zavagoza). AFA, 1956-7, 8-9, 30 .

2 A. Aronso, El grupo..., I 58.

3 T. Navarro Tomís, Manual de pronunciación española, Madrid, I96 I0, I90n.

4. TAVArro Tomís, El acento castellano, Madrid, 1935, 44.

- Soure la semejanza tonal del habla de tierra de Estella con el aragonés, este testimonio de un novelista: Fil hablante de aquella conarca nemplea un fácil y seguro castellano, plagado de voces que serán extrañas al de otra región y que, auncure por el acento recuerde la influencia aragonesa, son de segurisimo origen vascon. C. GndDenso, Mio Jurra, Pamplona, I943. 9.

Iîn curiosa coincidencia con csta opinión, cfr. § Io, final, donde se recoge un juicio anślogo formulado precisamente en Estella por un viajero alemán en I837.

- Según los datos obtenidos por M. ALVAR, El fuego y el léxico con él relacionado en la Návarra nordoriental. Miscelánea filológica dedicada a A. Griera, Barcelona, I955, I, 24. 
que debe considerarse esta posibilidad, al menos como una hipótesis, necesitada de más amplia verificación.

De su multisecular contacto con el vascuence podrían advenir al dialecto navarro algunos rasgos diferenciales dentro del panorama lingüistico iberorrománico. El deficiente conocimiento actual de aquella variedad dialectal impide hoy por hoy realizar el estudio de esta cuestión. No obstante, en los dos capitulillos siguientes abordo sendos casos concretos del contacto de ambas modalidades lingüísticas.

\section{El Romanzado}

Iil Valle del Romanzado, denominación vigente, es una demarcación territorial situada en la extremidad oriental de la Navarra media, próxima a Sangüesa y Javier. La más antigua mención conocida, Tierra romanzada, remonta a I6IO ${ }^{1}$. Resulta muy controvertida la justificación histórica de tal topónimo, por lo que presupone acerca de la época de la romanización o romanceamiento del territorio que designa. No resulta posible resolver aquí la cuestión, necesitada de más detenido examen, ni siquiera exponerla con detalle, para lo que remito a la bibliografía pertinente 2 .

Pero, en cualquier caso, puesto que a comienzos del siglo xvir ya se calificaba de romanzado al territorio $y$, dada la situación lingüística de su entorno, estimo que debió de ser un temprano foco romance en territorio de lengua vasca. Así lo afirman, sin entrar en la justificación explícita de su aserto, tanto Lacarra ${ }^{3}$ como Caro Baroja 4 . Con el propósito de volver sobre el tema en otra ocasión, anticiparé que entre los topónimos del Romanzado, tenidos como vascuences por algunos autores, se encuentra Domeño. Ninguna dificultad ofrece su relación con do m in i u m (Domeño, en Valencia;. Domeny, en Gerona; Sant Jaume dels Domenys, Tarragona), lo cual constituye un argumento a favor de la opinión que acabo de exponer.

1 F. IDOATE, Urraul, la Tierra romanzada y Lumbier, en El Pensamiento navarro, I7.xIr.67 y 22.xIr.67.

2 J. Yanguas y Miranda, Diccionario..., s. v.; A. MaricharaR y C. MLANRIQUE, Historia..., IV, 398; R. MENÉnDEz PIDAL, Toponimia..., 36-7; J. RUIz I) E. Oyag., El Romanzado, en Diario de Navarra, 2.vir.58. Cfr. también los estudios citados en la nota anterior y en la siguiente.

3 J. M. IASCARRA, El primer románico en Navarra. PV, I944, 5, 224.

- J. Caro BAROJA, Materiales..., I7. 
La datación más antigua que conozco de Domeño remonta a 1075, en un documento de Leire ${ }^{1}$ que alude, precisamente, al señor de Domeño. Posteriormente, registrados por Corona ${ }^{2}$, encuentro Dominu (Leire, I088), Domin (Leire, I088, II02, II2I, II25), Doming (II2I), Domenyo (Sangüesa, I473).

\section{El habla de la Cuenca de Pamplona}

De las relaciones entre vascuence y romance, reiteradamente aludidas en este trabajo, ofrece una interesante muestra el habla de la Cucnca de Pamplona, es decir, de la pequeña región natural, rodeada de montañas, que circunda la capital navarra.

De la antigüedad de tal concepto sociogeográfico constituye buena prueba el hecho de que ya en el Fuero general de Navarra (III, V, X) se consigne su delimitación. Según una interpretación folklorística, pertenecen a la Cuenca aquellos pueblos en los que se oyen las campanas de la catedral pamplonesa. Todavía hoy se designa, con cierta connotación peyorativa, a sus habitantes con el nombre de cuencos (que forman la mayor parte de los sabaderos, es decir, de los aldeanos que acuden al mercado sabatino de Pamplona). De ellos se escribía en el siglo pasado: "Los aldeanos son los habitantes de un espacio que se conoce con el nombre de Cuenca de Pamplona, y que desde la Capital se extiende en todas direcciones como dos lenguas, por término medio. lin estos hombres no se encuentra ninguno de aquellos sentimientos nobles que resaltan en los demás de la Provincian" ${ }^{3}$ y sigue una terrible invectiva (sólo comparable a la de Aymeric de Picaud) contra los cuencos, a los que se acusa de egoístas, envidiosos, mentirosos, holgazanes, pérfidos, etc. Indudablemente, el aludido escritor carga las tintas en su diatriba, verdaderamente feroz. Pero tanto su escrito como la mordaz réplica que suscitó 4 , sirven - por eso los he aportado- para mostrar la existencia de un grupo rural bien definido, específicamente motejado (aldeanos, cocos, cuencos) por sus vecinos.

Pues bien, sobre estos aldeanos - cuyo antagonismo con el habitante urbano se vislumbra en los datos consignados arriba- se ejercería

1 J. GoñI Gaztanimide, Calálogo del Becerro antiguo y del Becerro menor de I.eyre. $P V, 1963,24,165$.

2 C. CoRona, Toponimia..., s. v.

- I. SANZ y BNiza, Esiadistica de Navarra, Paimplona, I858, I6.

- I: Lncavri, Defensa de los aldeanos de la Cuenca de Pamplona, Pauplo11a, 1858 . 
pronto la influencia lingüística de Pamplona. Al acudir a ella, el vascohablante rural ${ }^{1}$ se vería obligado a darse a entender en romance, con la consiguiente erosión de su lengua nativa y familiar. La primera referencia que he encontrado de este fenómeno de contacto lingüístico data de más de un siglo. Perico Alejandría ${ }^{2}$, tras informar de que en Navarra la primera lengua es la "castellana o nacional, que se emplea en la parte oficial y pueblos de la rivera o tierra baja, fronterizos de las provincias de Zaragoza y Logroñol; la segunda, la euscara o vascongada, "cuyo uso abraza la región del Pirineo con sus ramificaciones montañosas", añade con su torpe prosa: "L a tercera es un dialecto de localidad encerrado en las aldeas inmediatas a la capital, teniendo algún contacto con algunos habitantes de la misma, a causa de la interpolación de las dos lenguas citadas; de modo que más bien es una corruptela de ambas con algún rastro de concesión». Como muestra del "dialecto o lengua mista" ${ }^{3}$. recoge la siguiente canción: "Joana-Mari coge el chico, / pero no lagas quilicas, / lo pondrás cucurubico / cuando quiera hacer chirricas».

Una información similar suministra Iribarren " al caracterizar la Cuenca de Pamplona como "la tierra donde la gente liabla ell una jerga, medio vascuence, medio castellanan, ejemplificándola con esta otra cuarteta: "El alcalde e Zabaldica / le echa a las berzas chungur, / en cambio le echa birica / el alcalde de Cizur».

1 Que el vascuence era la lengua de los cuencos todavia en i 858 , se desprende -en concordancia con los limites geográficos del vascucince en aquella fechadel opuísculo de Lacave antes citado, al asegurar éste, frente a Sanz y Baeza, "liablo su idioma" (3). Me parece interesante aducir también, con el mismo propósito, que uno de los soldados de Ispoz y Mina (Memorias del General Don Francisco Espoz y Mina, escritas por el mismo, Madrid, r85I, I, 35-7), I'ćlix Sarasa (Cholin), de Artica, en la Cucnca, a tres kilómetros de Pamplona, mo sabía escribir, leer, ni hablar castellano; comprendia si, la lengua castellana, mas uunca pudo decir en ella una cxpresión enteramente ajustada. Era el vascougado más cerrado que habia existido en Navarra». Recuerda Ispoz y Mina uno de los recados rerbales enviados por Cholin a su compañero Górriz: "Ahi te envias Cholin trescientas onzas; dis general que Cholin no tienes más. $Y$ la respuesta: "Dises general que está bien $y$ que cuides muchos portillos $y$ caminos."

2 PERICO ALEJANDRí $\Lambda$, El pamplonés. Guia de la ciudad y manual de curiosidad, Pamplona, I863, 96.

3 Esta afirmación recuerda la situación lingüística de Bilbao, que Mrcmílins (prólogo a E. DE ARRIAGA, Lexicón bilbatno, Madrid, 1960 ${ }^{2}$, 6) califica de lengua criolla, aportando en su justificación el siguiente testimonio: "Lil autor de un catecismo vizcaino inćdito, compuesto a fines del siglo xVIU, apunta con ironfa que los bilbalnos hablan una especie de tertium quid que no es vascuence ni romance."

4 J. MI. IRIBARRIN, Burlas y chanzzas, Pamplona, I95I, 69. 
LA FRONTERA NAVARRO-ARAGONESA $(1.035-1.135)$

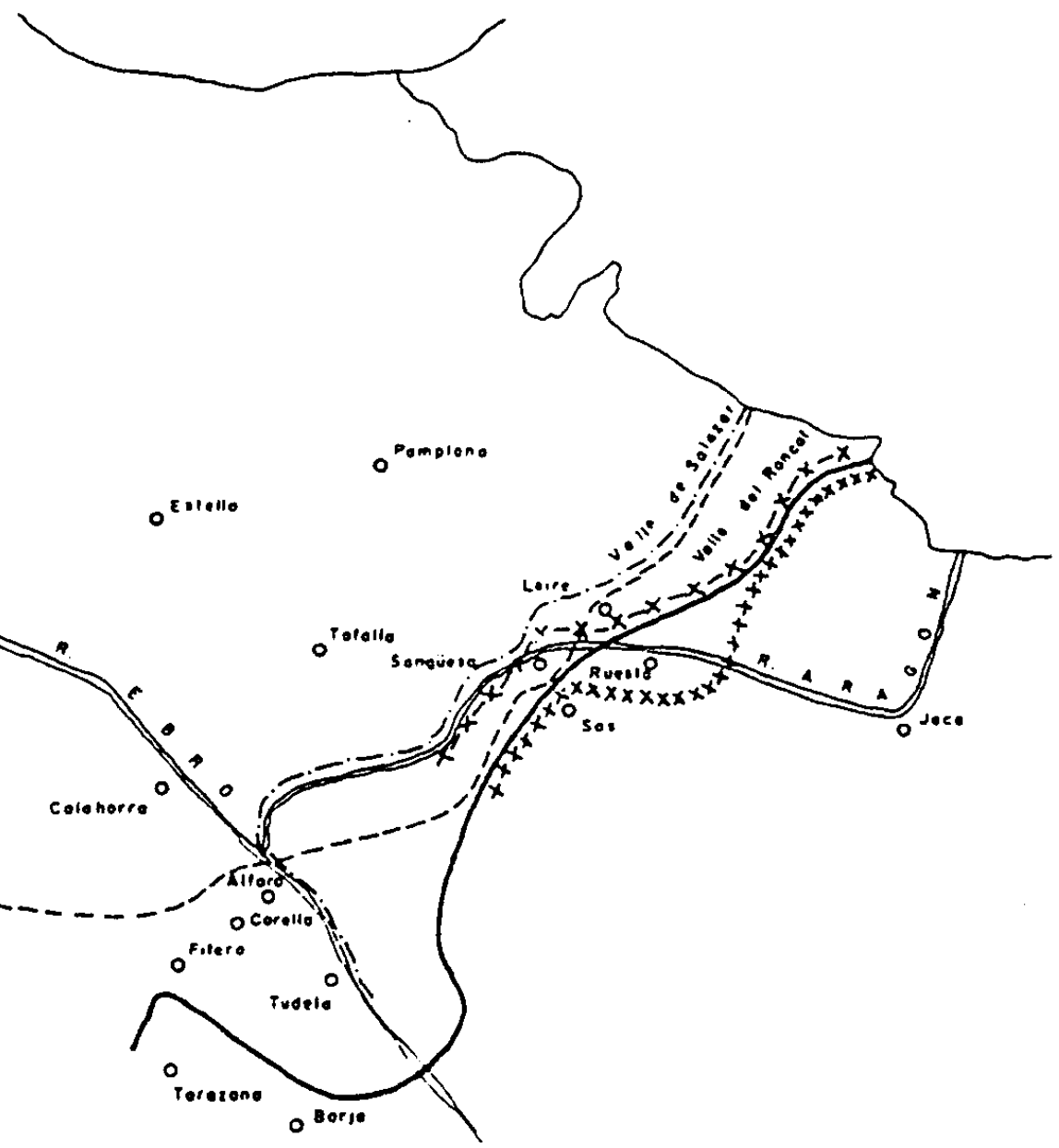

A PRINCIPIOS DEL REINADO DE RAMIRO I 


\section{NAVARRA BAJO SANCHO EL FUERTE (1.194-1.234).}

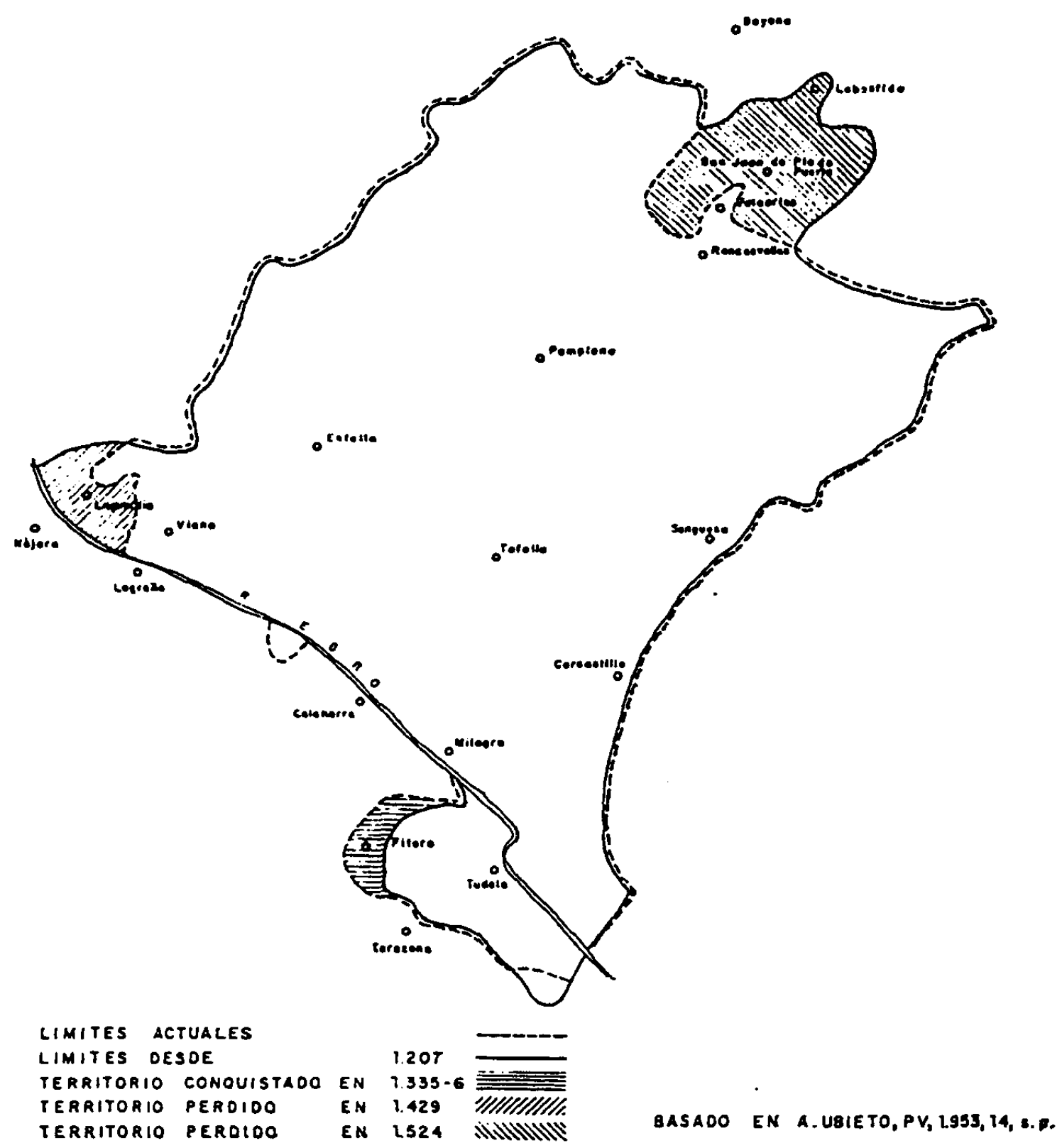


Pero la principal fuente para el conocimiento de esta habla, ya desaparecida, son los artículos periodísticos de $A r a k{ }^{1}$, que en breves y sencillos cuadros costumbristas, cuyo interés radica especialmente en captar situaciones coloquiales de la vida aldeana, refleja el habla cotidiana de los habitantes de la Cuenca. Sobre una estructura sintáctica y un léxico decididamente encuadrados en el castellano vulgar, saltan con frecuencia rasgos fonéticos, voces $y$, sobre todo, construcciones atribuibles al vascuence. He aquí algunas muestras: "Les dije que nosotras no cstariamos idas porque habiamos salido almorzadas de casa y a más teniamos en el zare a cada dos cerras de pan y chistor" (10).- "Yo creia ese pa vender que teniais" ( $\mathrm{I}_{3}$ ).- ¿Quién t'ha dicho a tu yo pa cueser que estaba querido ese hilo?" (I7).- "El shendero pa ir al cielo era mucho estrecho $y$ no hacia pasar por ande los cines" (2I).- "Quejar si t'haces, de vicio hace ser》(IOI).- "Médicos y boticas aunque con haber, la gente, tarde que temprano, morir si hace" (I27).- "¿Vestido muevo te vas a estar hecha o ast?" (159).

También pueden observarse algunas peculiaridades, escasas, que remontan al navarro medicval: adaqui, adalli, aday, drccho, jóvena, etc.

Arako convierte ciertos procedimientos sintácticos (por ejemplo, el uso de hacer + infinitivo para señalar el sentido dinámico) debidos a la construcción vascuence en determinados casos, en esquemas de uso constante que, en muchas ocasiones no responden, por tanto, a un supuesto modelo con egin 'hacer'. Pero su intención paródica, con la inevitable exageración de los aspectos típicos, permite conocer los rasgos más característicos del habla de la Cuenca ${ }^{2}$.

La labor lingüística realizada por Arako hace recordar empresa análoga llevada a cabo por Juan del Enzina con el habla rural salmantina,

1 Arako ('el de marras') fue el seudómimo literario de Cándido Testaut Macaya, periodista pamplonés nacido en I 885 y fallecido en 1956. Conocedor del vascuence descle niño, durante toda su vida sostuvo constante relación con habitantes de la Cuenca de Pamplona, en varios lugares de la cual tenia parientes. Resultado de esas relaciones son los articulos aparecidos en el Diario de Navarra (excepcional y esporádicamente en otras publicaciones) desde I9ro hasta su muerte, bajo el título de Dialogando. Durante bastantes meses después, el citado periódico repitió la publicación de artículos ya aparecidos: tal era el interés de los lectores. En 1947, Ediciones Lreyre, de Pamplona, recogió en un volumen, con el mismo título de Dialogando, una selección de dichos articulos. A José Javier Testaut, bijo dcl autor y también exceleute periodista, debo algunas de estas noticias.

2 Los pamploneses de cierta eclad reconocen unánimemente la fidelidad de Arako respecto de sus modelos idiomáticos. Es de desear que pronto pueda aparecer un estudio detailado de sus artículos, solsre los que recibió correspondencia epistolar - Loy perdida- de Meuéndez l'idal. 
a través del sayagués. En ambos casos se caracteriza al campesino de los aledaños de la ciudad por medio de sus rasgos lingüísticos diferenciales.

Precedente de esta elaboración del habla popular navarra es un memorial anónimo ${ }^{1}$ dirigido a las Cortes de Navarra en I8I7. Su autor, titulándose El procurador de los labradores, parodia el lenguaje de éstos. Junto a numerosos vulgarismos (metátesis, aféresis, aglutinación del artículo, cierre de la vocal final, etc.), el texto denota la influencia del vascuence en el vocabulario (chistor, atapurres, pitarra, mezeta, etc.), quizá en algunas construcciones y claramente en la mayoría de los antropónimos: Garro, Burdinerreca, Marruca, Zopolo, Zarcume, Vurızuri, etc.

\section{Io. La castellanización lingüística}

La aludida falta de estudios filológicos sobre la documentación navarra medieval no permite llegar a conclusiones precisas y garantizadas sobre el proceso de castellanización del habla de Navarra. Sin embargo, me atrevo a afirmar decididamente, con base en la lectura de buena parte de la documentación publicada y de otra inédita, que la desaparición de los rasgos lingüísticos peculiares y su sustitución por los castellanos se realizó más temprana y también más rápidamente en Navarra que en Aragón. Asimismo, que el fenómeno aludido había alcanzado ya gran intensidad mucho antes de la unión política con Castilla, de modo que, al verificarse ésta, el proceso de unificación lingüística estaba ya prácticamente consumado en lo que se refiere a la lengua escrita.

Buena prueba de todo lo arriba expuesto es, por presentar un caso concreto, la situación lingüística que ofrece el testamento (I4I2) de Carlcs III, documento de la cancilleria regia, cuyo original se conserva, editado y estudiado por Saralegui ${ }^{2}$. La lengua de este texto coincide con el castellano, en todos los casos, respecto de las soluciones de $j$-, -ct-, -ult -, que el navarro tenía propias; a la vez que para $l j$ vacila promediadamente entre el resultado autóctono y el castellano. Esta última es la misma situación denunciada por Menéndez Pidal ${ }^{3}$ a propósito de la Crónica de García de Eugui, que se escribía hacia r387. Por el con-

1 Ha sido publicado y coneutado por J. MI. IRIBARREN, El comer, el vestir $y$ la vida de los navarros de 1817 , a través de un unemorial de ratonera". $P V$, 1956 . I7. $473-85$.

2 C. SARAIEGUI, El testamento (I4I2) de Carlos III de Navarra. Edición crltica, estudio ling üistico y vocabulario (en prensa).

3 R. MEnÉndez Pidat, Roncesvalles. RFE, I917. 4, Irg. 
trario, en Zaragoza "en I 475 el predominio de $l l$ es total" y solameute (a partir de I5I8. se cumple la implantación de $j$ ", si bien aún perdura $l l$ en textos del siglo xvir ${ }^{2}$.

No resulta fácil explicar por qué Aragón conservó durante más ticmpo sus peculiaridades lingüísticas, toda vez que sus relaciones con Castilla fueron más intensas que las de Navarra durante la Edad Media - liasta el punto de haber entronizado una dinastía castellana- y culminaron en una unión política más temprana y más estrecha. En el Diálogo de la lengua ${ }^{2}$ pregunta Marcio: "CCómo en Aragón y Navarra, aviendo sido casi siempre reinos de por si, se habla la lengua castellana?" Valdés, que no les reconoce un habla propia, a diferencia de otras regiones, le responde con dos razones: Haberse conservado la lengua antigua (es decir, originaria comunidad con el castellano), "aunque creo que también lo aya causado la mucha comunicación que éstas dos provincias an siempre tenido con Castillan. Sin embargo, esta razón histórica no resulta suficiente, pues, según un criterio de tal especie, Navarra debiera haber conscrvado más tiempo su modalidad lingüística, a la vista de los hechos histúricos antes presentados.

Prescindiendo de explicaciones poco comprobables - cual puede ser una mayor voluntad de fidelidad idiomática, que sería propia del carácter tradicionalmente atribuído a los aragoneses- encuentro una motivación diferencial (que no ha de ser necesariamente la única) en el cultivo literario alcanzado por ambas regiones. Mientras que para Aragón puede fijarse una nómina de textos literarios medievales - si bien la crítica actual va reduciéndola $o$, al menos, rebajando el carácter aragonés de tales textos- $\mathrm{y}$ aun hablar de una continuidad literaria que, tras una prolongada debilitación se ensancha de nuevo -aunque sea bajo manifestaciones ínfimas- en el siglo pasado ${ }^{3}$, nada similar, por el contrario, se encuentra en Navarra, que presenta un claro vacío literario \&. Antes de abordar este tema, hay que anticipar que tal precaria situación prestaba especial facilidad a la difusión de la literatura castellana, una de las vías de la castellanización peninsular.

Aunque se trate de una noticia de relieve limitado, resulta significativo, en el orden de cosas apuntado, que para festejar a Carlos II a su regreso de Francia - país con el que tan ligado estaba - acudieran a

1 M. Alvar, El dialecto..., 192.

2 J. DE VALDÉs, Diálogo..., 34.

3 Poesia dialectal española. Fist., selecc. y notas de MI. AL, VAR, Madrid, 1965, 26.

- Sobre el ambiente cultural de Navarra en la edad media, cfr. F. ELfAS DE TIEJADA, La literatura politica..., r99-212. 
Navarra los juglares del rey de Castilla ${ }^{1}$. También son conocidas, dentro del siglo siguiente, las andanzas por Navarra de Juan de Valladolid.

Algunas particularidades del castellano hablado en Navarra quedaron consignadas en $\S 7$, final, y también en $\S 9$, al caracterizar lingüisticamente la Cuenca de Pamplona. He aquí otras noticias del siglo pasado, que recogen la impresión que producía el habla castellana de los navarros, $U_{n}$ viajero extranjero ${ }^{2}$ que llega a Estella anota "la rudeza de los navarros, cuyo tono, aun cuando quieren ser amables, está lleno de rudeza. Cuando os aborda un navarro, su "usted", saliendo del fondo de las fauces, suena ya como una altanería. Sospecho que han tomado estas formas acerbas de sus vecinos aragoneses". Ros de Olano ${ }^{3}$ refiere que al ser detenido un vecino de Irarrosoaña, aldea próxima a Pamplona, "preguntado su nombre, edad, estado, etc., los dijo en regular castellano, si bien con acento navarro". De su primer encuentro, en Inglaterra, con Espoz y Mina, escribe Alcalá Galiano ": "El trato con gente principal no había afinado mucho sus modales ni corregido su lenguaje, que seguía siendo el de un campesino navarro, y más tosco que de lo que de su presencia debla esperarsen; y reproduce, a continuación, un breve discurso, compuesto de frases deshilvanadas y palabras entrecortadas, del que merece señalarse la forma cuidiao 'cuidado'. In los primeros años del último siglo, un viajero francés ${ }^{5}$ asegura que el habla de Navarra, la cual no constituye ningún dialecto particular, "est mélée [...] de basque, de catalan et de français».

\section{La lileratura navarra}

Una rápida visión histórica permite comprobar la inexistencia de una literatura lingüísticamente navarra, hecho cuyas graves consecuencias no resulta preciso encarecer a los efectos aquí considerados.

Menéndez Pidal ${ }^{6}$ señaló que ni una resonancia navarra, tanto en prosa como en verso, se conserva de un acontecimiento de la trascendencia literaria de Roncesvalles. García de Eugui, por ejemplo, a fines del

1 J. Yanguas y Miranda, Diccionario..., III, I85. Tambićn R. MIEnt́ndez PIDAl, Poesia juglaresca $y$ origenes de las literaluras románicas, Madrid, I957, 215 y passim, recoge diversas noticias de juglares. castellanos en Navarra.

2 F. Licinowskr, Recuerdos de la guerra carlista (1837-1839). 'Trad. de J. MI. AzcoNa. Madrid, I942, 78.

- A. ROS DE OlaNo, Episodios militares, Madrid, I884, IIO.

- A. Alcalí Galiano, Obras escogidas. Fid. de J. Canpos, Madrid, I955, I, 2 rob.

- A. DE LABORDE, Itinéraire descriptif de l'Espagne, Paris, I8392, V, 300-I.

- R. Mínéndez PIDAI, Roncesvalles..., r95. 
siglo xiv no sabe de él más que el Toledano. Respecto del pocma épico Roncesvalles, "fuera de la grafía navarro-aragonesa, el fragmento presenta pocos dialectalismos propios de la región orientaln, de modo que unuestro manuscrito presenta un desequilibrio entre la grafia y las formas dialectales; su carácter navarro se debe, pues, en gran parte a un amanucnse, y acaso a éste se le pueden atribuir no sólo en gran parte, sino en su totalidad, los clialectalismos navarros" ${ }^{1}$. Más adelante razona que el cantar se compuso en Castilla y no en Navarra, donde se copió. La opinión de Horrent ${ }^{2}$ es coincidente a este respecto, pues sostiene para Roncesvalles "une origine plutôt navarraise qu'aragonaise. Les dialectismes sont le fait du copiste. Aucun d'entre eux n'est susceptible d'être attribué à l'auteur du cantary.

Una nutrida nómina de juglares, algunos de los cuales cree vascos, en torno a la corte de Carlos III, reveló Menéndez Pidal ${ }^{3}$. Pero ninguna noticia queda de sus desconocidas composiciones.

En el Cancionero de Herberay des Essarts ${ }^{4}$, compilado entre I46I-I464 en la corte de Doña Leonor, infanta de Navarra, es Carlos de Arellano el único pocta del que casi con seguridad puede afirmarse que fuera navarro. Pues bien, en sus dos poesías recogidas (números CLXXVI y CLXXVII) no existe la menor muestra de navarroaragonés, aunque no falten rasgos lingüísticos de esta especie en otras composiciones del mismo cancionero (car, comuna, adj. fem., atraye, posseyr, adreça, ad, nadi, otri, ys, qui, seyer, etc.). El único rasgo específicamente navarro del texto radica en la grafía goa (agoas, lengoa, antigoas, igoal, santigoada), pero no aparece nunca quoa, del mismo modo que para $\tilde{n}$ se utiliza ny (stranya, senyalada) y no yn, grafía más caracterizadamente navarra.

Otro de los escasos poetas navarros medievales conocidos es Fran-

1 Ibid., I 20. El caso inverso seria el del $A$ uto de los Reyes Magos, si es cierta la lipótesis propuesta por $J$. Corominas (reseña en $N R F H$, 195S, 12, 75n), quien espera probar que lo escribió «un poeta del Alto Aragón o Navarra, que mezclaba con su lengua materna la hoiné catalano-occitanan; "más tarde el texto fue copiado cn 'Toledo o cn otra parte de Castilla, dándole la forma acastellanada en que ha llegado a nuestras manos". R. I.APISSA (Sobre el Auto de los Reyes Magos: sus rimas anómalas y el posible origen de su autor, en el Homenaje a $F$. Krïger, Mendoza, I954, II, 591-9. Ahora en De la edad inedia a mestros dias, Madrid, I967. $37-47)$ sostiene la procedencia gascona del autor.

2 J. Horrent, Roncesvalles, Paris, 1951, 55.

- R. Mentendez Pidar., Poesia juglavesca..., 394-7; otras referencias en $9 \mathrm{I}-3$. Com anteriotidad, J. Yanguas y MiRnNda, Diccionario..., III, 185-6. Más noticias en F. Idoaxr, Rincones de la historia de Navarra, III. I'amplona, 1966, 44 I-52.

- Cancionero de Herberay des Essarls. Lid. de Cir. V. Aubrux, Burdeos, I95I. 
cisco de Amézcoa (fl. a mediados del siglo xv); pero las obras que de él se conservan están escritas en catalán ${ }^{1}$.

Antón de Moros, que Morel-Fatio ${ }^{2}$ cree aragonés por su apellido y por algunos rasgos léxicos y morfológicos, cuyo número podría aumentarse 3 , de sus poesías, quizá pudiera ser navarro, no solamente por las peculiaridades lingüísticas citadas, sino por el siguiente dato biográfico: su adversario poćtico, Gonzalo Dávila, se hace eco (VIII, 27) de las acusaciones que en Tafalla corren sobre él; al menos, pues, hay que afirmar que vivió en esa población navarra. También Cotarelo ${ }^{4}$ supuso que Moros era navarro, sobre la base de que lo era Gonzalo Dávila. Claro que esta última creencia de Cotarelo resulta inaceptable, pues llega a ella por el simple hecho de que una composición suya figure en el cancionero de Herberay. El origen castellano de Gonzalo Dávila -aun prescindiendo de la consideración de su nombre- está bien probado documentalmente 5; además, como informa Moros $(\mathrm{V}, 70)$ : "porque os dezian marranclión, / vos salistes de Castillan. E1 Cancionero general recoge una composición suya, cuyo título revela un dato biográfico que aquí interesa consignar: [Coplas] de Gonzalo Dávila en la guerra de Navarra (fol. CCXXXI). En correspondencia con esta circunstancia está el hecho de que en las citadas coplas aparezcan algunos rasgos lingüísticos que pueden atribuirse al área navarroaragonesa ( $y s$, cras, honor, fem.).

A la vista de lo hasta aquí expuesto, hay que sentar que el romance navarro no parece estar presente en la poesía medieval del reino, mientras que existen manifestaciones -escasas en número, pero de notable entidad- en occitano ${ }^{6}$.

Por eso no deja de ser sorprendente que haya que esperar hasta fines del siglo XVI para que un poeta tudelano, Jerónimo Arbolanche,

1 Cfr. A. PAGÉs, La chanson catalane du Navarrais Francesch de Amezcua, susr l' Immaculée Conception. BH, I945, 47, 26-33.

2 A. MIOREL-Fario, Le débat entre Antón de Moros et Gonzalo Dávila. Ro, IgoI, 30, 49-64. Cito las poesías de estos autores por el número romano que llevan eu esta edición.

s Tuvido (I, I 7); qualque (I, 23); rosigar (V, 32); caldra (V, 56); dasse (V, I ro) gataz (IX, II 6 ); fer (passiun).

- E. Cotarifo, reseña del artículo de Morel-Fatio, en RELH Igor, r, I9rb.

- Cfr. los datos biográficos recogidos por AUBRON en el estudio preliminar a su ed. del cancionero, LXXXVI-LXXXVII.

- Además de las poesias sueltas, se conservan dos obras de notable importancia y volumen: la Cansó de la crozada, de Guillermo de Tudela, y el poema que Irraregui, su descubridor, demominó La guerra civil de Pamplona, de Guillermo Anelier. 
ofrezca el máximo conocido, entre autores navarros, de elementos dialectales navarroaragoneses (adreçar, esprimentado, piadad, rabaño, senal, mas., favor, fem., vigor, fem., con mi, con ti, nadi, otri, cualque, estara, is, ante con ante, finiestra, gramen, masida, royo, señar, tiemblo, yusmeter, etc.) en su producción literaria ${ }^{1}$ que, curioso contraste, es de marcadísima tendencia culta. Ahora bien, estos elementos dialectales están muy diseminados a través de un extenso poema, Las $A$ bidas, de manera que no configuran especificamente ni siquiera alguna parte - fragmento de la obra.

Hasta aquí, la situación de la poesía navarra, desde el ángulo de su caracterización lingüística. Queda por examinar la prosa.

Con plena pujanza se manifiesta el romance navarro en el Liber Regum, cuya posición lingüística quedó antes señalada ( $\S 6)$; pero, desgraciadamente, constituye una muestra casi única, con la modesta excepción de las noticias genealógicas denominadas Corónicas navarras (cfr. § 4). No existen apenas o no han sobrevivido otras manifestaciones de la prosa histórica de tan clara filiación navarra. Del texto citado hay que saltar a la Crónica general de España, de Fray García de Eugui 2 , de fines del siglo XIV, cuya castellanización ya quedó antes indicada ( $($ Io), aunque se mantengan grafias navarras caracteristicas (aynno, goalardon, Afriqua, etc.) y parcialmente rasgos fonéticos y gramaticales (clamar, dreyto, mellor, silvestras, otri, daron, estar pequeño, sobre tii, etc.). Análoga situación presenta la Crónica (I405) de García López de Roncesvalles ${ }^{3}$ en cuanto a su lengua (Espayna, Ronqual, ailli, plenos, conseilleros, constreita, ienero, reliquias qui su suegro li avia dadas, lur, rendient, venientes, plus, car; pero mucho, ocho, muger, etc.) y más castellanizado se encuentra el texto de la Crónica de los Reyes de Navarra, del Príncipe de Viana 4 , que no se vale del romance local para ninguna de sus otras producciones literarias. Por eso resulta extraña

1 F. Gonzílez-OLLÉ, Lengua y estilo en Las Abidas de Jerónimo Arbolanche. $P V, 1967,28,34-35$.

2 Fr. GARCía de Eugur, Crónica general de España. Ed. de J. EyzaguIRre. $A U C h$, I907, I20, 603-49, 737-80r; I908, I22, I-68, 387-5I5.

Cfr. S. HoNokE-Duvi:RGt, Etudes d'historiographie navarraise. La Chronique de Garcia d'Eugui, évêque de Bayonne. BH, I942, 44, I7-39.

3 He consultado el ms. existente en la Biblioteca de la Diputación de Navarra, cuya letra es de fines del siglo xvi o del xvin. Lo tardio de la copia garantiza la autenticidad de los rasgos dialectales que eucierra, pero no que se hayan respetado todos los originarios.

Cfr. 'S. DuverGté, La Chronique de Garci López de Roncesvalles, trésorier de Navarre. BH, 1935, 37, 437-53.

- Ed. de J. Yanguas y Mliranda, Pamplona, I843. 
la afirmación de que "escribe el romance navarro a maravilla" (cfr. § 2) y sólo en un sentido muy amplio ha de tomarse la afirmación de Menéndez Pidal ${ }^{1}$ de que "el Príncipe de Viana [escribía] en navarro".

Junto a sus poesías en catalán, la traducción de las Ethicas (Zaragoza, 1509), de Aristóteles, se hace al castellano (aunque no falte algún rasgo dialectal: esleer, diferecer, endrefar, honras comunas); asi se advierte explícitamente en el prólogo anónimo de la obra: "passó del lalin a la lengua castellana) (IV), que precisa las palabras del própio Príncipe (en un segundo prólogo) de que hizo la versión sdel latín en nuestro romances (2r) y ratifica, como he dicho, la lectura del texto ${ }^{2}$. En dicho prólogo, el traductor manifiesta su preocupación lingüística por usar las palabras más exactas (así, esfuerço en vez de fortaleza) o por forjar otras, inexistentes en latín y griego (así, comedimiento). Quizá es tal actitud la que ha dado motivo para afirmar - con una generalización, a mi entender, excesiva - que el Príncipe de Viana es uun sabroso manejador de palabras burgalesas" ${ }^{3}$.

En la historiografía navarra posterior, el proceso de castellanización lingüística está ya totalmente consumado.

Me parece que ha pasado inadvertida la existencia de una versión navarra de la Biblia. En la Crestoniatia, de Menéndez Pidal, se editan varios fragmentos de Versiones castellanas de la Biblia en el siglo XIII. Pues bien, los correspondientes al manuscrito escurialense I-j-8, de "letra gótica aragonesa del siglo XIV o XV" ${ }^{5}$, son indudable-

2 R. MIrníndez PidaI, En torno a la lengua vasca, Madrid, 1962, 55.

2 De esta traducción de Aristóteles existe un manuscrito del siglo XV en el British Mruseum, según el catálogo de Gayangos, cuyo conocimiento seria conveniente para ratificar las anteriores afirmaciones, aunque me parece poco probable que pueda desvirtuarlas. Debe hacerse notar que no ofrecen plena garantia las ediciones existentes de las obras del Principe de Viana y que, incluso, no está claramente establecida su nómina.

3 F. ELIÁAS DE TEJADA, La literatura politica..., $2 \mathrm{Ir}$.

- El hecho a que aludo en el texto ha sido anteriormente señalado por IAN MACPHERSON. BHS, 1967, 44, I26.

El carácter aragonés del manuscrito I-j-8 fue denunciado por S. BERGER, Les Bibles castillanes. Ro, 1899, 28, 385; A. CASTRo, Biblia medieval romanceada, Buenos Aires, I927, XVII; R. OROz, El vocabulario del ms. escurialense $I-j-8$ según la "Biblia medieval romanceada". BFChile, 1944, 4, 273; y M. MORREALI, Arcatsmos $y$ aragonesismos en el Salterio del manuscrito escurialense $I-j-8$. $A F A$, I96I-2, II-2, 7. De modo general, puede decirse que todos ellos coinciden en suponer que se trata de un original castellano que ha sido alterado por un copista aragonés.

8 R. MEnÉndez PIDAx, Crestomatla del español medieval, I, Madrid, I965, 269-72. 
mente de filiación navarra, juzgar a por sus grafías (quoal, eilla, estreillas, peynnas, cauaillo, cueillo, saynna, etc.), y también por varios rasgos fonéticos, morfológicos y léxicos (amplura, claman, guardest, lamben, ploro, prea, plunia, espandiente, car, segude, taiantes, caussantes, lis, aplcgauan, etc.). Pesc a que los rasgos típicamente castellanos del texto son constantes, no creo que los navarros se deban a la copia ", pues la misma alternancia se observa en documentos originarios de Navarra.

La traducción del Libro de Tobias, según el citado ms. escurialense, ha sido cuidadosamente editada por M. Morreale ( $B F$, I959, II, 57-7I).

En Noches de invierno (Pamplona, I609; hay ed. moderna a cargo de L. M. González Palencia. Madrid, I942), colección de novelas cortas de Antonio de Eslava, "natural de la villa de Sangüesa", abundan rasgos léxicos y gramaticales de carácter local. Los varios que cita como dialectales el editor moderno (prólogo, XXIX) no tienen carácter navarro (salvo, parcialmente, drecho y gerundios como tuviendo, pusicndo); en cambio hay que citar assi bien (pp. 20, 42, 78, 206, 245, etc.); cualque (24); ullra (88, I03, I82, I94); sintaxis de cada (356); otri (358). Merece señalarse la coincidencia con Arbolanche, pues se repite la paradoja de un autor de estilo enorinemente enfático que deja escapar estas formas vulgares.

Se comprenderá, pues, perfectamente, tras este balance, que a diferencia de otras áreas idiomáticas españolas, la moderna literatura navarra carezca de un pasado lingüístico que continuar. $\mathrm{Ni}$ a mediados del siglo pasado Navarro Villoslada, en sus novelas históricas -especialmente idóneas por tal condición-, ni posteriormente Hermilio Olóriz en verso o Arturo Campión y Juan Iturralde en prosa, autores todos ellos que buscaron su inspiración en las tradiciones heroicas y costumbristas de Navarra, prestan atención a los precedentes lingüísticos patrios ${ }^{2}$. Igual ocurre, ya en nuestro tiempo, con Félix Urabayen, excelente recreador del paisaje físico y humano de Navarra. En una obra tan auténtica y profundamente costumbrista como Bajo los robles navarros - por citar una de sus novelas-, sólo el lenguaje

1 No obstante, segúu la autorizada opiuión, que quiero agradecer aquí, de don Rafael Lapesa, la existencia de tales rasgos se debería a la copia de un texto original castellano por escribas navarros, como ocurre incluso ren textos alfonsies en que intervinieron Juan de Aspa o Guillén Arremón de Aspan.

2 A lo sumo, por dar color de época, emplean a veces algún arcaismo léxico o sintáctico, que no resulta necesariamente navarro o que claramente no lo es.

Io mismo puede decirse de algunos escasos pasajes de fabla. Ajena a la cuestión aqui tratada es la presencia de vasquismos - palabras o frases- en las obras de Campión. 
empleado, de trabajado barroquismo, plagado de referencias cultas, queda absolutamente al margen de aquella finalidad caracterizadora (el hecho de encabezar cada capítulo con unos versos de Antonio Machado denota esa misma desviación).

Mariano Arrasate Jurico anota a pie de página los navarrismos y vasquismos léxicos que utiliza en sus novelas, cuyo carácter se revela en los subtítulos (La expósita. Tipos y costumbres de Navarra. Pamplona, r929.-Macario. Novela de tipos y costumbres de Navarra. Pamplona, I932); procura reflejar, en algunas palabras, la pronunciación vulgar y 110 sé hasta qué punto son intencionados o espontáneos algunos esquemas sintácticos (si no tendría confianza..., me iria.-Yo no queria que tc lo diriamos). Con mayor constancia recoge Carmelo Galdeano (Mio Jurra. Pamplona, I943) el habla vulgar de Estella, junto al deficiente castellano de los nativos de lengua vasca. Pero ni en uno ni en otro escritor puede decirse - dada la parquedad con que se utili$\mathrm{za}$ - que la modalidad lingüística empleada caracterice sus novelas.

En El tributo de los días (Madrid, I968), de Manuel Iribarren, el autor cree oportuno colocar un vocabulario final para facilitar al lector la comprensión de algunas palabras, pocas, usadas por los personajes. Pero esta particularidad no ha de interpretarse, a mi parecer, dentro de una línea de revalorización o revitalización de una tradición lingüísticoliteraria, sino motivada por la tendencia naturalista en que se inscribe la novela (descripción de la vida rural de la Ribera navarra). Il recurso al vocabulario recuerda, por su intención, a Pereda o a Goy o, en última instancia, a Rómulo Gallegos o a Miguel Angel Asturias.

Aunque he querido, para mayor exactitud, detenerme en los casos expuestos (que agotan todos los posibles), en realidad apenas tiene sentido plantearse la cuestión de la tradicionalidad, pues los precedentes no existen prácticamente, como ha podido comprobarse. Así, a comienzos del siglo xvir a nadie se le pasaba por la cabeza la posibilidad de una literatura lingüísticamente navarra, ni aun procediendo con el criterio de acoger todas las manifestaciones idiomáticas antiguas 0 modernas del reino, incluso otras ajenas a él. En efecto, en los certámenes literarios que se convocan en Pamplona durante los años I609 y $16 \mathrm{IO}^{1}$ se admiten poesías en castellano, vascuence, latín y-para

1 Relación de las fiestas que el Ilmo. Señor Don Antonio Venegas de Figueroa, Obispo de Pamplona, hizo el dia del Santissimo Sacramento [...] con las poestas que fueron premiadas conforme a los certámenes, Pamplona, 1609.-Fiestas del Corpus que el año r6ro hizo el Ilustrissimo Señor Don Antonio Venegas de Figueroa, Obispo de Pamplona, con un dialogo, cartel poético y poesias premiadas, Paniplona, 16ro. 
lo burlesco- portugués y vizcaíno. Indudablemente que esta enumeración (prescindiendo de los dos últimos miembros) ha de interpretarse como una declaración de las únicas modalidades lingǘsticas que se reconocen, de algún modo, propias de Navarra. Nadie se acuerda ya del idiona de la ticrra de Navarra.

I2. Final

La aparición de un romance autóctono en Navarra plantea peculiares problemas - no abordados por la dialectología española- respecto de otras áreas iberorrománicas, por cuanto que surge en un medio geográfico que, siglos después, conservará todavía el vascuence como su lengua habitual ( $\$$ o). De igual modo, durante la época medieval se da la extraña situación de todo un reino que habla vascuence (la mayoría de sus ciudadanos no conoce otro medio de expresión), pero que jamás lo escribe; toda su documentación, todo su derecho público y privado se consigna en latín o-progresivamente, en paralelismo cronológico con áreas vecinas- en romance. En un romance propio (las manifestaciones documentales de romances ultrapirenaicos no ofrecen apenas relieve en un macroanálisis; cfr. mi estudio La lengua occitana en Navarra, RDTP, I969, 25, 285-300), segunda lengua de una minoria dirigente, lengua oficial del reino de Navarra.

No faltan explícitas declaraciones en este sentido, al menos desde I344, cuando la frontera meridional del vascuence corría al sur de Estella y Olite; especialmente significativa es la que figura en el acta de la coronación (r390) de Carlos III: previamente a la transcripción -en su versión original- del juramento leído por el rey, se advierte, en el latín del acta, que estaba escrito in ydiomate Nanarre terre, lo que permite conocer con plena certeza que así se consicleraba a la modalidad románica antes aludida $(\S \mathrm{I})$.

Apenas existen estudios filológicos sobre la documentación navarra medieval, lo que impide por ahora caracterizar bien su lengua, englobada generalmente en la denominación de navarroaragonés ( $(2)$, partiendo de su identificación -más admitida que detalladamente comprobadacon el aragonés $(\S 3)$. Aunque en menor número que en otras regiones españolas, no faltan de Navarra textos publicados que permitan su análisis filológico; una serie de trabajos en curso - de los que el presente pretende ser su planteamiento inicial - permite abrigar esperanzas de alcanzar un mejor conocimiento del navarro (§ 4).

A la vista de los hechos histórico geográficos, no puede explicarse 
la aparición del romance en territorio navarro como resultado de una suplantación del vascuence por invasión, desde su periferia, de una modalidad lingüística ajena. Este fenómeno ocurre, sí, desde el siglo xvr, con la creciente castellanización, que va empujando hacia el norte los límites del vascuence. Pero desde varios siglos antes -y esto es $10 \mathrm{im-}$ portante-, el romance ha ido progresando en territorio vascuence al ritmo de la expansión política del reino de Navarra y aún más allá, es decir, hasta el Ebro y Rioja. Ahora bien, esa progresión no supone una continuidad geográfica desde su centro inicial de irradiación, sino una difusión social que afecta a un número proporcionalmente escaso de habitantes del reino.

Junto a las circunstancias históricogeográficas, diversas razones culturales y políticas hacen creer que el aludido núcleo originario deba situarse, a principios del siglo $x$, en la zona de Sangüesa y Leire, el área más romanizada y cristianizada de la periferia de la Navarra vascónica. De ella procede la estirpe Jimena, dinastía que presenta características más carolingias que la anterior, más vascónica, de los Aristas y Velascos. Resulta interesante observar que la toponimia, euskera, de la citada región ofrece con regularidad los efectos de la diptongación románica (Lumbier, Navascués, etc.).

El monasterio de Leire (cuyos volúmenes latinos admira el año 848 San Eulogio de Córdoba) debió de jugar un papel de primera importancia en la formación y posterior difusión del romance navarro. Su influencia -en muy diversos órdenes - fue extraordinaria en los origenes de Navarra; con él mantuvieron, en los siglos iniciales, una estrecha vinculación tanto la corte real como el obispado de Pamplona. Su actitud lingüística diferencial queda reflejada en multitud de alusiones del tipo: dicitur in basconea lingua; bascones vocant, etc. (\$5).

Convertido en lengua oficial de la cancillería real, el romance navarro llegaba a todos los rincones del reino. Es decir, su conocimiento se hacia imprescindible para determinados grupos sociales y profesionales, para todo individuo que no quisiera quedar marginado. Se explican así tanto su difusión social como el hecho de que hasta hace un siglo se haya hablado con intensidad la lengua vasca en Pamplona. El debilitamiento, más social que territorial, según queda dicho, del uso del vascuence a lo largo de la edad media, facilitaria posteriormente el retroceso geográfico de sus límites ante la presión castellanizante (cfr. mi estudio Vascuence y romance en la historia lingiiística de Navarra. BRAE, r970).

Numerosas ciscunstancias comunes llevan a pensar que el romance del este navarro y el del oeste aragonés tuvieron que constituir en sus 
orígenes una misma modalidad idiomática, de la que sería muestra el Liber Regum, alternativamente atribuido, según sus estudiosos, a una u otra variedad dialectal ( $(6)$.

Tal unidad lingüística parece quedar confirmada en los estudios dialectológicos modernos, aunque los datos aportados respecto del área navarra resulten aún escasos ( $§ 7)$.

La interferencia de vascuence y romance da lugar a situaciones peculiares, como la del valle del Romanzado ( $(8)$; y ofrece manifestaciones muy marcadas en el habla de la cuenca de Pamplona, modalidad hoy en trance último de desaparición $(\S 9)$.

Si el romance navarro se fue imponiendo, lentamente, al vascuence, a su vez $-y$, claro está, mucho antes de que se consumase tal procesoiba siendo suplantado por el castellano de un modo mucho más rápido, a partir de una temprana castellanización. Este segundo proceso está consumado a fines del siglo xv; más rápidamente, pues, que en Aragón ( $§$ Io).

Probablemente no resulta ajeno a este fenómeno el de la inexistencia de una literatura lingüisticamente navarra. El cantar de Roncesvalles no parece de origen navarro; ni siquiera la trascendencia histórica -especialmente para Navarra- y literaria del hecho que recoge aquel poema, obtiene ecos propios en Navarra (a fines del siglo xIV, Garcia de Eugui -autor de una crónica muy castellanizada - no sabe más de dicho suceso que el Toledano) (§ II).

F. GonzÁlez-Ollí́

Universidad de Navarra. 